In cooperation with the U.S. Fish and Wildlife Service

\title{
Occurrence of the Diamondback Terrapin (Malaclemys terrapin littoralis) at South Deer Island in Galveston Bay, Texas, April 2001-May 2002
}

Open-File Report 03-022

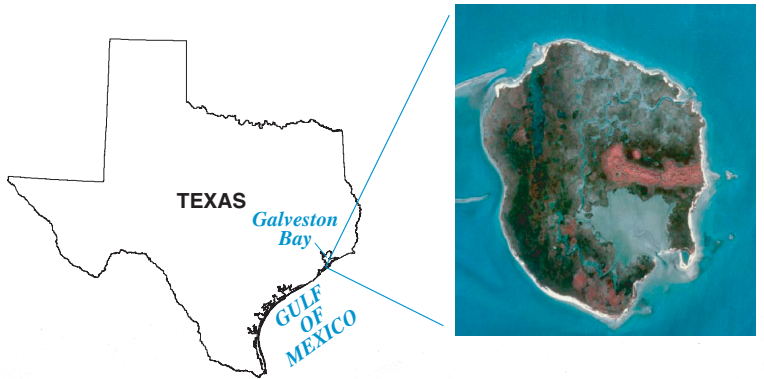

U.S. Department of the Interior U.S. Geological Survey 


\section{Cover:}

Drawing of Diamondback terrapin by L.S. Coplin, U.S. Geological Survey. 
U.S. Department of the Interior

U.S. Geological Survey

\section{Occurrence of the Diamondback Terrapin (Malaclemys terrapin littoralis) at South Deer Island in Galveston Bay, Texas, April 2001-May 2002}

By Jennifer L. Hogan

U.S. GEOLOGICAL SURVEY

Open-File Report 03-022

In cooperation with the U.S. Fish and Wildlife Service 


\section{U.S. DEPARTMENT OF THE INTERIOR}

Gale A. Norton, Secretary

\section{U.S. GEOLOGICAL SURVEY}

Charles G. Groat, Director

Any use of trade, product, or firm names is for descriptive purposes only and does not imply endorsement by the U.S. Government.

For additional information write to

\section{District Chief}

U.S. Geological Survey

8027 Exchange Dr.

Austin, TX 78754-4733

E-mail: dc_tx@usgs.gov

Copies of this report can be purchased from

U.S. Geological Survey

Information Services

Box 25286

Denver, CO 80225-0286

E-mail: infoservices@usgs.gov 


\section{CONTENTS}

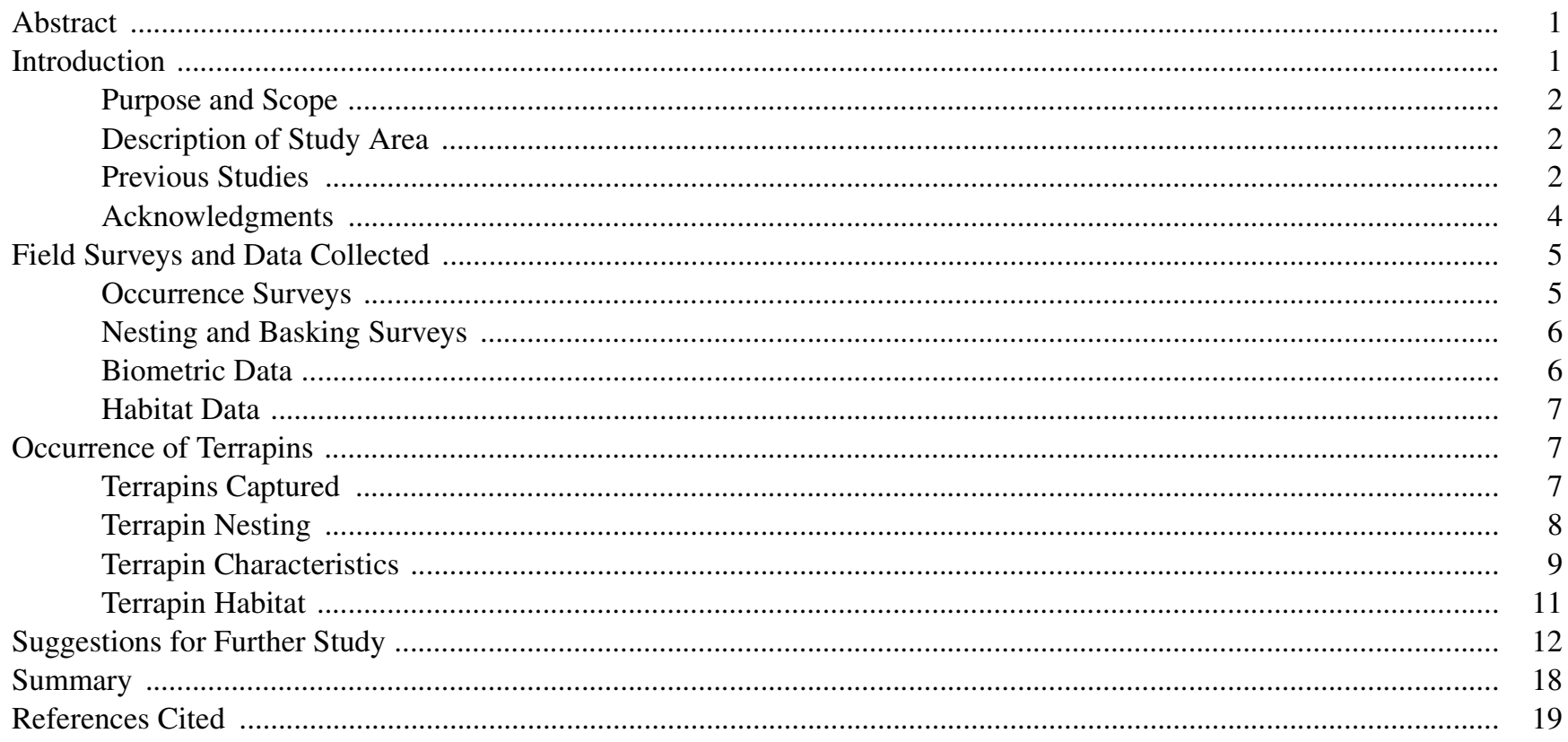

\section{FIGURES}

1. Map showing location of South Deer Island in Galveston Bay, Texas ............................................................ 3

2. Digital orthophoto showing South Deer Island and locations of field surveys, April 2001-May $2002 \ldots \ldots \ldots \ldots . . . . . \quad 4$

3. Photograph showing modified crab trap with chimney ................................................................................. 5

4-5. Graphs showing:

4. Catch per unit effort (CPUE) of Diamondback terrapins and by-catch at South Deer Island, Texas, April 2001-May 2002

5. Correlation of monthly catch per unit effort of (a) terrapins and crabs and (b) terrapins and fish at South Deer Island, Texas, April 2001-May 2002

6-7. Photographs showing:

6. Female Diamondback terrapin covering her nest site on South Deer Island, Texas ............................... 10

7. Diamondback terrapin egg from a nest on South Deer Island, Texas ................................................... 10

8. Graph showing female and male straight-line carapace lengths of Diamondback terrapins captured at South Deer Island, Texas, April 2001-May 2002

9. Boxplots showing size data from Diamondback terrapins captured at South Deer Island, Texas, April 2001-May 2002

10. Graph showing correlation of straight-line carapace length with mass of Diamondback terrapins captured at South Deer Island, Texas, April 2001-May 2002

11. Boxplots showing condition factor of female and male Diamondback terrapins captured at South Deer Island, Texas, April 2001-May 2002

12-14. Photographs showing variation in:

12. Color and markings among Diamondback terrapins captured at South Deer Island, Texas, April 2001-May 2002

(3)

4


15-17. Graphs showing:

15. Frequency of occurrence of female and male Diamondback terrapins with lesions captured at South Deer Island, Texas, April 2001-May 2002

16. Frequency of occurrence of female and male Diamondback terrapins with barnacles and algae captured at South Deer Island, Texas, April 2001-May 2002

17. Maximum water temperature recorded manually at South Deer Island and recorded by National Ocean Service data logger in Galveston Channel during terrapin collection periods, July 2001May 2002

18. Historical photographs (a, b) and digital orthophoto (c) of South Deer Island, Texas, from 1930, 1958, and 1995

\section{TABLES}

1. Summary of terrapin field surveys, South Deer Island, Texas, April 2001-May 2002 .................................. 5

2. Summary of terrapin capture and biometric data, South Deer Island, Texas, April 2001-May 2002 ................ 20

3. Maximums of field parameters recorded during periods of terrapin collection, South Deer Island, Texas, April 2001-May 2002

4. Vegetation species or substrate with at least 20 percent relative frequency along six transects, South Deer Island, Texas, April 2001-May 2002 


\title{
Occurrence of the Diamondback Terrapin (Malaclemys terrapin littoralis) at South Deer Island in Galveston Bay, Texas, April 2001-May 2002
}

\author{
By Jennifer L. Hogan
}

\section{Abstract}

One-hundred thirty-five terrapins were captured (116 individuals, 19 recaptures) in occurrence and nesting and basking surveys at South Deer Island in Galveston Bay, Texas, during April 2001-May 2002. Along the southern shore of the island, terrapins were captured in crab traps placed in shallow water offshore; in the lagoon on the island, terrapins were captured by hand while walking along the shore. In the nesting and basking surveys, areas of the island with continuous patches of exposed shell typically were checked twice a day for nesting and basking terrapins, except during the last 2 months of the study, when more intensive monitoring was conducted. The occurrence surveys resulted in 119 terrapins captured in crab traps and nine captured by hand around the lagoon. The nesting and basking surveys yielded seven terrapins. Only one was nesting, although the nest is believed to be the first documented terrapin nest found in Texas. Three terrapins were captured swimming near shell beaches, and three more were captured basking on shell beaches. The most terrapins were captured during April-May 2001 and April-May 2002. Biometric data collected on terrapins captured showed size dimorphism on the basis of sex. The median female straight-line carapace length was 17.8 centimeters, 1.4 times larger than the median male carapace length, 13.1 centimeters. The median female mass was 1,021 grams, 2.9 times larger than the median male mass, 354 grams. Intra-specific variation occurred in the colorations and markings of terrapins captured. Anomalies-lesions, deformities, barnacles, and algae-were common among terrapins captured. Both lesions and deformities were more common among males than females. Dominant vegetation or substrate associated with terrapin habitat included saltwort, slender seapurslane, seabeach orache, shell, and woody debris.

\section{INTRODUCTION}

Diamondback terrapin are a species of concern in Texas, and the status of each terrapin subspecies is either unknown or declining in every range in the United States (Seigel and Gibbons, 1995; Wood and Herlands, 1997). Few data have been collected on the occurrence of the Diamondback terrapin in Texas, and even fewer data on the subject have been published. The study documented in this report is believed to be the most comprehensive to date on the Diamondback terrapin in a single area in Texas.

The Diamondback terrapin is the only reptile of 270 species globally known to live exclusively in brackish waters, which include brackish coastal marshes, tidal flats and creeks, and lagoons behind barrier beaches extending from Cape Cod, Mass., to Mexico (Gunter, 1981). The Diamondback terrapin is an emydid turtle that occupies a genus composed solely of its own species, Malaclemys terrapin. Seven subspecies of terrapins have been documented in the United States. Only one subspecies, M. t. littoralis, inhabits the Texas coast. Its range extends from western Louisiana south to Mexico (Cagle, 1952; Smith and Smith, 1979).

Diamondback terrapin populations began declining in the 1800 s, when they were regarded as a culinary delicacy and fished for meat (Babcock, 1926; Coker, 1920). Public demand led to over-harvesting, and terrapin populations began declining on the East Coast at the beginning of the last century. Despite efforts at 
terrapin farming (Hildebrande, 1929, 1933), by the mid1930s terrapins were no longer found in New York, Connecticut, Rhode Island, or Cape Cod (Carr, 1955), although they have since re-populated some areas. In most of its ranges, terrapins are legally hunted at 127 millimeters (5 inches) in median plastron length (Bishop, 1983).

Commercial crab traps have caused and continue to cause appreciable terrapin mortality. On the coast of New Jersey, at least 30,000 to 40,000 terrapins drown each year in crab traps (Wood and Herlands, 1995). At least one-third of all terrapins caught in crab traps drown because they cannot reach the surface to breathe (Wood and Herlands, 1995). In South Carolina, about 11,000 crab traps capture about 1,760 terrapins each year (Bishop, 1983). The Texas Parks and Wildlife Department (TPWD) reports that State game wardens retrieve more than 2,500 of the thousands of traps lost or abandoned in Texas bays each year (Kristen Everett, Texas Parks and Wildlife Department, written commun., 2002). The Texas Legislature passed a bill that created an abandoned crab trap removal program that allows TPWD to enforce a crab trapping closure in Texas bays for 2 weeks during early spring to remove lost or abandoned traps. TPWD organizes public participation in its trap-removal program. Lost or abandoned crab traps can move into shallow water with the tide in areas where terrapins congregate, thus contributing to terrapin mortality.

Nest-site disturbance by structures such as bulkheads or fencing can destroy entire nesting colonies because terrapins return to the same locations to nest each year. In areas with bulkheads, exposed beaches are lined with large barriers that block the natural ebb and flow of tides. Female turtles might continue to nest in these areas, and their nests become inundated by high tides, drowning the embryos. Nest-site disturbance can force overcrowding of suitable nesting locations or nesting along shoulders of busy highways, which results in high female mortality (Wood and Herlands, 1997). If nest-site disturbance extirpates an entire breeding colony of closely related turtles, the genetic make-up of the population might become altered. Genetic differences within a species could ultimately decrease over time as habitat loss increases and reduce recruitment, fitness, and adaptability of individuals (Scribner and others, 1995).

\section{Purpose and Scope}

The purpose of this report is to document the results of field surveys and data collected by the U.S. Geological Survey (USGS), in cooperation with the U.S. Fish and Wildlife Service, on the occurrence and nesting behavior of Diamondback terrapin at South Deer Island in Galveston Bay, Texas. Occurrence surveys were conducted along the southern shore of South Deer Island each month during April 2001-May 2002 and along the shore of a lagoon on the island during the same period, excluding November-December 2001. Nesting and basking surveys were conducted along the southern shore of the island each month during April 2001-May 2002, excluding November-December. The report describes the findings of the surveys - that is, terrapin occurrence and nesting behavior at South Deer Island. Also included are summaries of biometric and habitat data collected during the field surveys.

\section{Description of Study Area}

South Deer Island is a 0.3-square-kilometer island located 1.6 kilometers north of Galveston Island in Galveston Bay (fig. 1). South Deer Island is a privately owned island containing multiple waterways. The island is lined with cordgrass, Spartina $s p$. Cordgrass acts as a soil stabilizer, reduces the risk of erosion, and serves as a barrier to waves and storms. Despite the abundance of cordgrass on the island, South Deer Island loses land each year to subsidence. On the southeastern side of the island, a small lagoon has formed inside the island and has converted marsh habitat to open water (fig. 2). The lagoon is a heavily silted body of water with open access to the bay. Prior to the study, Diamondback terrapins had been observed throughout the island's lagoon and marshes and closely offshore of the island (John Huffman, U.S. Fish and Wildlife Service, oral commun., 2002).

\section{Previous Studies}

In 1984, TPWD sent about 1,150 questionnaires to commercial crab trappers, fishermen, coastal fisheries biologists, and coastal game wardens to obtain information on the range of terrapins along the Texas coast. Historical terrapin sightings were reported at various coastal locations from Nueces Bay to Galveston Bay from 1973 through 1984 (D.W. Mabie, Texas Parks and Wildlife Department, written commun., 1988). 


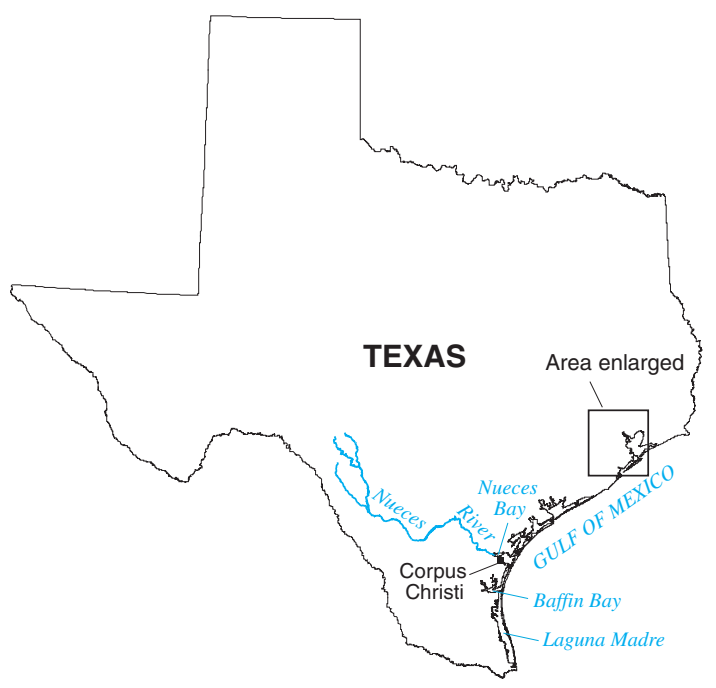

LOCATION MAP
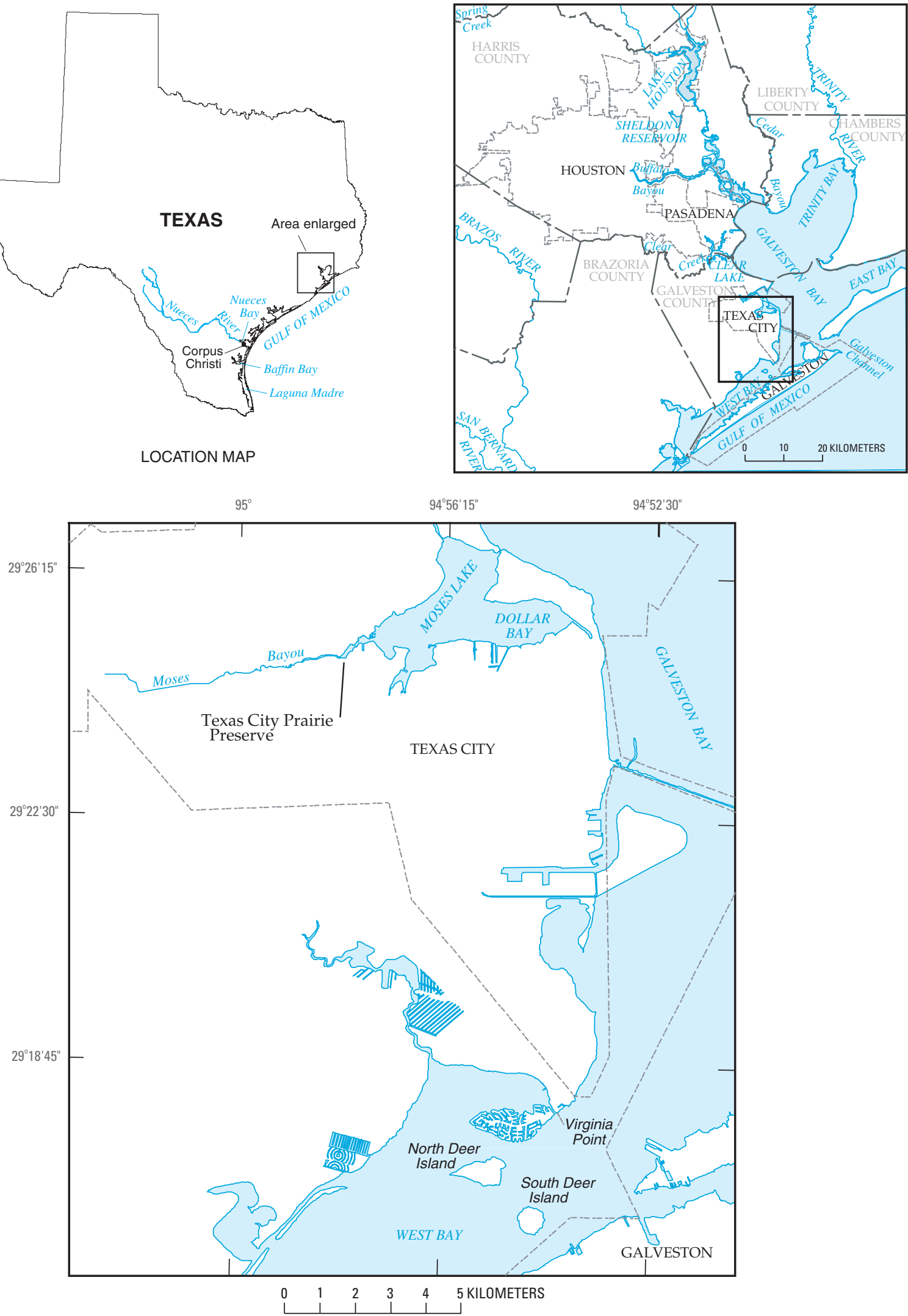

Figure 1. Location of South Deer Island in Galveston Bay, Texas. 


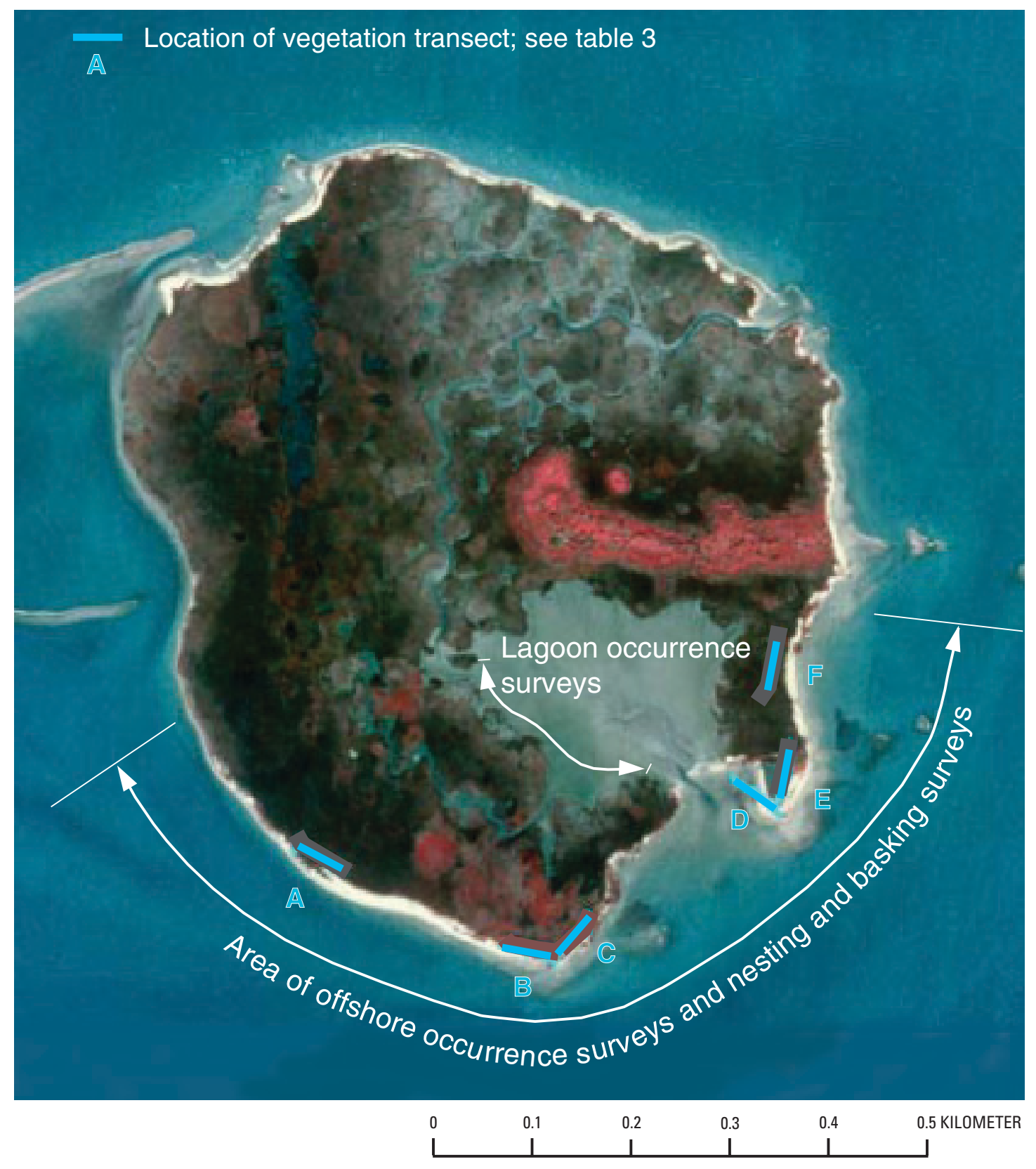

Figure 2. Digital orthophoto showing South Deer Island and locations of field surveys, April 2001-May 2002.

A study was conducted in 1997 on the coast near Corpus Christi (K.A. Halbrook, Texas A\&M University, and L.F. Elliot, Texas Parks and Wildlife Department, written commun., 2000). During the study, 109 individual terrapins were captured near Nueces Bay and the mouth of the Nueces River. This study indicated that terrapins are most abundant near riverine habitat with salt marshes, shell islands, and oyster-shell reefs in shallow turbid water.
Another study (Huffman, 1997) compiled data on sightings of Diamondback terrapin in several bays near Galveston. One terrapin was captured in that study.

\section{Acknowledgments}

The author thanks the U.S. Fish and Wildlife Service for their cooperation and field assistance; National Marine Fisheries Service in Galveston for use of their 
boating equipment; Texas Natural Resources Information System for maps and geographic information system (GIS) support; Alecya Galloway, Environmental Institute of Houston, for sharing knowledge of historical terrapin habitat; Southwest Texas State University, Botany Department; and TPWD, National Audubon Society, and numerous volunteers for field assistance.

\section{FIELD SURVEYS AND DATA COLLECTED}

In this study, two principal types of field surveys were conducted-occurrence surveys and nesting and basking surveys (fig. 2; table 1). The objective of the occurrence surveys was to obtain temporal distribution and biometric data pertaining to terrapins on or near South Deer Island. The objective of the nesting and basking surveys was to obtain information on nesting behavior and habitat and to obtain biometric data on terrapins. Vegetation surveys, considered part of the nesting and basking surveys, were conducted to obtain nesting habitat data.

Table 1. Summary of terrapin field surveys, South Deer Island, Texas, April 2001-May 2002

\begin{tabular}{ccc}
\hline $\begin{array}{c}\text { Type of } \\
\text { survey }\end{array}$ & $\begin{array}{c}\text { Period of } \\
\text { survey }\end{array}$ & $\begin{array}{c}\text { Frequency } \\
\text { of survey }\end{array}$ \\
\hline Occurrence & April 2001-May 2002 & $3-8$ days/month \\
$\begin{array}{c}\text { Occurrence } \\
\text { (lagoon) }\end{array}$ & $\begin{array}{c}\text { June-October 2001; } \\
\text { March-May 2002 }\end{array}$ & $2-3$ days/month \\
$\begin{array}{c}\text { Nesting and } \\
\text { basking }\end{array}$ & $\begin{array}{c}\text { April-October 2001; } \\
\text { January-May 2002 }\end{array}$ & \\
\hline
\end{tabular}

Basic reconnaissance was conducted in March 2001 to verify shell substrate (potential terrapin habitat) and the accessibility of the island. Terrapin surveys began near South Deer Island in April 2001. April was chosen as the first month of surveys because other terrapin subspecies have been known to end their winter hibernation in the early spring and the southern subspecies have been documented to begin their nesting in the early spring (Carr, 1955).

\section{Occurrence Surveys}

Two methods to collect terrapins were used in the occurrence surveys: Along the southern shore of the island, terrapins were captured in crab traps placed in shallow water offshore; in the lagoon on the island, terrapins were captured by hand while walking along the shore.
Crab traps have been used successfully to collect terrapins in Texas bays in the previous studies noted. The crab traps allow for the collection of by-catch data on crabs and other terrapin prey; the height of the traps allows for tidal fluctuations without the risk of completely submerging traps; and they are easily anchored with rebar to prevent tipping. Crab traps with chimneys were constructed by molding two crab traps together to allow turtles to breathe (fig. 3). Traps were anchored with rebar to prevent tipping, buoyed, and baited with shad. Traps were placed in water less than 1 meter deep about 25 meters offshore of continuous patches of exposed shell, which is potential terrapin nesting habitat. Traps were equally spaced 50 meters apart along transects perpendicular to the island.

During April 2001-May 2002, an average of 13 crab traps was deployed 3 to 8 days each month, the maximum number of traps that could be transported safely offshore in a 5-meter boat. Four traps were set

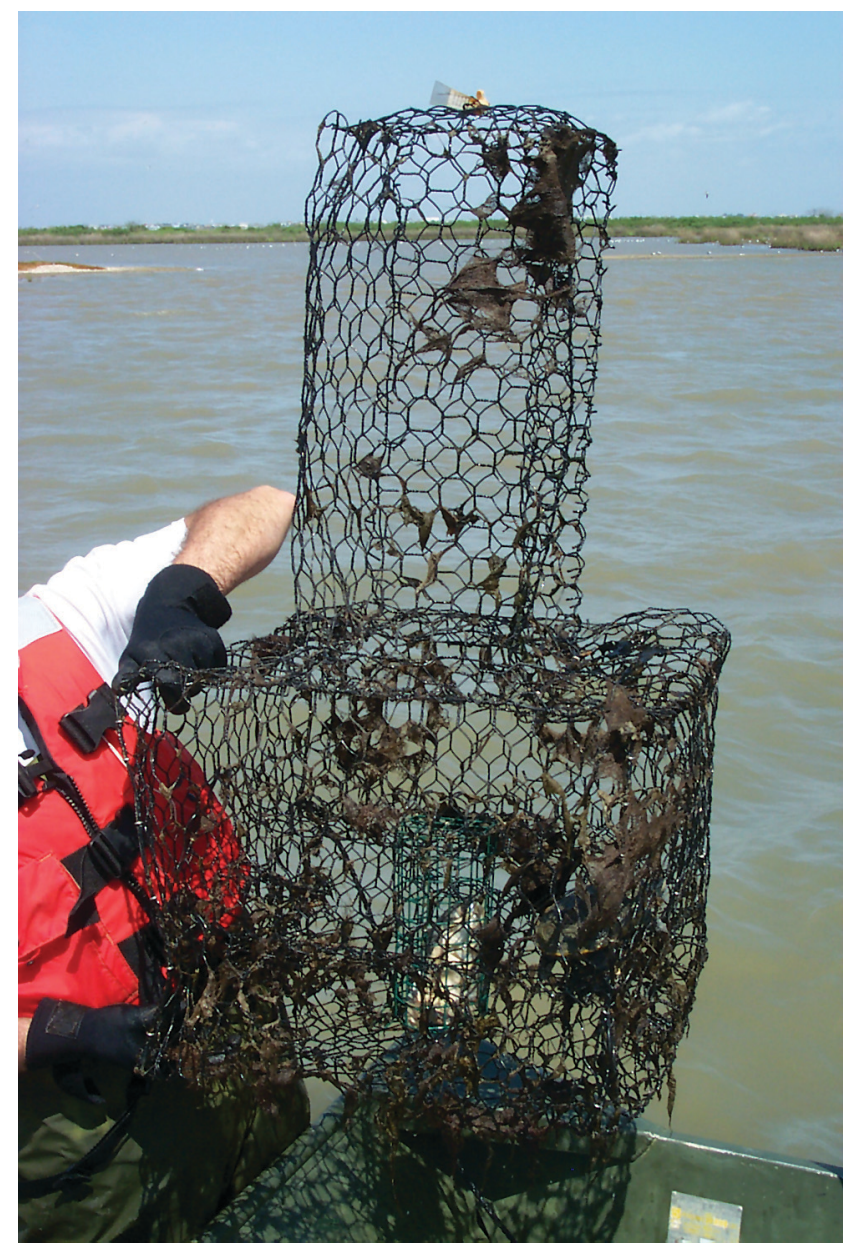

Figure 3. Modified crab trap with chimney. 
during April-May 2002 to compare catch rates with the previous year. Fewer traps were set during April-May 2002 than during previous months to avoid interfering with the nesting activity of females attempting to swim ashore and thus increase the probability of finding a nesting female during surveys. At the beginning of each monthly survey, traps were set at about 9:30 a.m., left overnight, and checked each morning thereafter at about 9:30 a.m. Traps were checked once in the afternoon about 1 p.m. if the catch rate was relatively high.

Because the number of traps set and the number of days the traps were set varied each month, the number of terrapins (excluding recaptures on the same day) per trap-day, or catch per unit effort (CPUE), was computed each month to standardize collections in traps each month for comparison. For instance, if 13 traps were set for 5 days and eight terrapins were captured, the CPUE for that month was

8 terrapins $/(13$ traps $)(5$ days $)=0.12$ terrapin/trap-day .

In addition to terrapin data, by-catch (crabs and fish) data also were compiled so that CPUE for crabs and fish captured in traps could be computed to document potential prey base.

Occurrence surveys also were conducted in the island lagoon two to three times each month. The lagoon occurrence surveys consisted of walking along the southern part of the interior lagoon and surveying the channels and side pools that extend about 40 meters landward from the lagoon. The lagoon occurrence surveys were conducted along the southern part of the lagoon because of the concentration of meandering channels that extend from the lagoon on the southern side. The lagoon surveys focused on the transition zone between the water and vegetation, the likely area for basking terrapins based on the author's observations.

\section{Nesting and Basking Surveys}

Nesting and basking surveys were conducted on South Deer Island during April 2001-May 2002 except during November-December (table 2, at end of report); nesting and basking surveys were not conducted during these 2 months because no terrapins were sighted in the open water and no terrapins were captured in crab traps during November-December. Areas of the island with continuous patches of exposed shell typically were checked twice a day for nesting and basking terrapins, except during the last 2 months of the study, when more intensive monitoring was done. During April-May
2002 , beaches were monitored continuously starting at 10:30 a.m. and ending at 2:00 p.m. More intense monitoring was done during this period because the single nest found the previous year was found at the end of April.

The protocol upon finding a nesting female was to obtain biometric data (discussed below) after nesting to avoid interfering with nesting. Eggs were excavated and removed from the nest with care to maintain orientation, counted, and individually measured for length and width to the nearest tenth of a centimeter using calipers. Eggs were replaced in the nest in the same orientation and reburied while compacting the same nest medium.

Nests were flagged about 0.3 meter landward and to the right side of the clutch of eggs when facing away from the water, and locations of successful land captures of basking terrapins were staked at the collection site.

\section{Biometric Data}

Biometric data were obtained on all terrapins captured in the occurrence surveys and the nesting and basking surveys. These data comprised straight-line carapace length and width (to the nearest tenth of a centimeter), straight-line plastron length and width (to the nearest tenth of a centimeter), mass to the nearest ounce (reported in grams), and the presence of anomalies, including numbers of lesions, deformities, algae, barnacles, parasites, and naturally occurring scars or markings. Terrapins were measured with calipers and weighed with a hanging scale. Terrapin mass was obtained by subtracting the mass of a mesh bag from the mass of the bag and the terrapin. Each terrapin was released at the location where it was captured unless otherwise noted. A digital photograph was taken of the carapace, plastron, and any external anomalies. Scute abnormalities and the presence of eggs (determined by palpitating females) were recorded for terrapins captured in April and May 2001.

Algae samples were collected from terrapins in September 2001 and March 2002 to identify the species attached to the carapace. Algae samples were collected by incising a small section of a scute from the carapace including the attachment surface of the algae to aid in algal identification. Algae samples were preserved in 10-percent buffered formaldehyde and sent to Southwest Texas State University, Botany Department, to be identified to the lowest taxon. 
A condition factor was computed for each terrapin to standardize comparisons of sexes, ages, and sizes. The condition factor was defined as the mass in grams divided by the straight-line carapace length in centimeters.

Captured terrapins were notched with a triangular file on the marginal scutes. Notching was done to ensure against collecting duplicate data from recaptured individuals. Each terrapin was marked with a unique pattern and recaptures were noted and verified.

\section{Habitat Data}

At each crab trap, environmental data, considered part of the description of terrapin habitat, were collected one to two times each month during July 2001-May 2002. The data include location (global positioning system [GPS] coordinates), water temperature, salinity (dissolved solids), dissolved oxygen, conductivity, and $\mathrm{pH}$. All location coordinates were recorded using a Garmin hand-held GPS. Water-quality data were collected using a YSI600R four-parameter meter or a Quanta Hydrolab at each crab-trap site.

Air and water temperature also were retrieved from a daily monitor because the temperature recorded at each site was not continuous. Daily air temperature at Galveston Channel, about 11 kilometers northeast of South Deer Island, was obtained from the National Weather Service. Daily water temperature in Galveston Channel was obtained from a continuous data logger maintained by the National Ocean Service.

Habitat data collected at each land-capture site include percentage of vegetative cover, distance (to the nearest centimeter) from closest vegetation, height (to the nearest centimeter) of closest vegetation, distance (to the nearest 0.1 meter) to water, nest medium, nest depth (to the nearest centimeter), maximum nest width (to the nearest centimeter), presence of nest predator, species of nest predator, and GPS coordinates.

Vegetation surveys were conducted in July 2001 to identify the plant (and substrate) composition of potential terrapin nesting habitat on South Deer Island. Six transects were randomly selected along the continuous areas of shell along the south-southeastern shore of the island (fig. 2). The south-southeastern shore was chosen for vegetation surveys because of the concentration of continuous and exposed shell beaches. At each location, a 50-meter transect was surveyed in a straight line at the edge of dense vegetation. A compass bearing was recorded at the beginning point of every survey, and coordinates were collected at the beginning and end of each transect. Plant species or exposed substrate were recorded each centimeter along a transect and tallied to determine the frequency of plant species or substrate. Vegetation transects and data were plotted in a GIS to illustrate the plant community structure along areas of potential terrapin nesting habitat. Vegetation data were analyzed in a GIS to determine the frequency of plant species or exposed substrate along areas of potential terrapin nesting habitat.

To evaluate habitat change over time on South Deer Island, two historical aerial photographs of the island were analyzed and rectified to a USGS digital orthophoto of the island (Moring and Setser, 2000). Aerial photographs of South Deer Island in 1930 and 1958 and a digital orthophoto from 1995 were obtained from the Texas Natural Resources Information System. Ground control points were selected from scanned images of the aerial photographs and from the digital orthophoto. After the aerial photographs were georeferenced into a GIS, the boundary of each of the three images was digitized and overlaid for comparison.

\section{OCCURRENCE OF TERRAPINS}

\section{Terrapins Captured}

During April 2001-May 2002, 135 terrapins were captured in occurrence and nesting and basking surveys at South Deer Island (table 2). The occurrence surveys resulted in 119 terrapins captured in crab traps and nine captured by hand around the lagoon. The nesting and basking surveys yielded seven terrapins. Only one was nesting, although the nest is believed to be the first documented terrapin nest found in Texas. Three were captured swimming near shell beaches, and three more were captured basking on shell beaches from 2.4 to 9.0 meters from the edge of water.

Of the 135 terrapins captured, 116 were unique individuals, and 19 ( 15 females and four males) were recaptures. One additional female was recaptured the same day and thus not counted as a recapture. Sixteen unique individuals ( 12 females and four males) were recaptured; one female was recaptured three additional times, thus the recapture total of 19 . No population estimates for the study area were made because of the relatively small number of individuals captured.

Fifty-six females and 56 males (unique individuals) were captured in occurrence and nesting and basking surveys. Three terrapins captured were not counted 


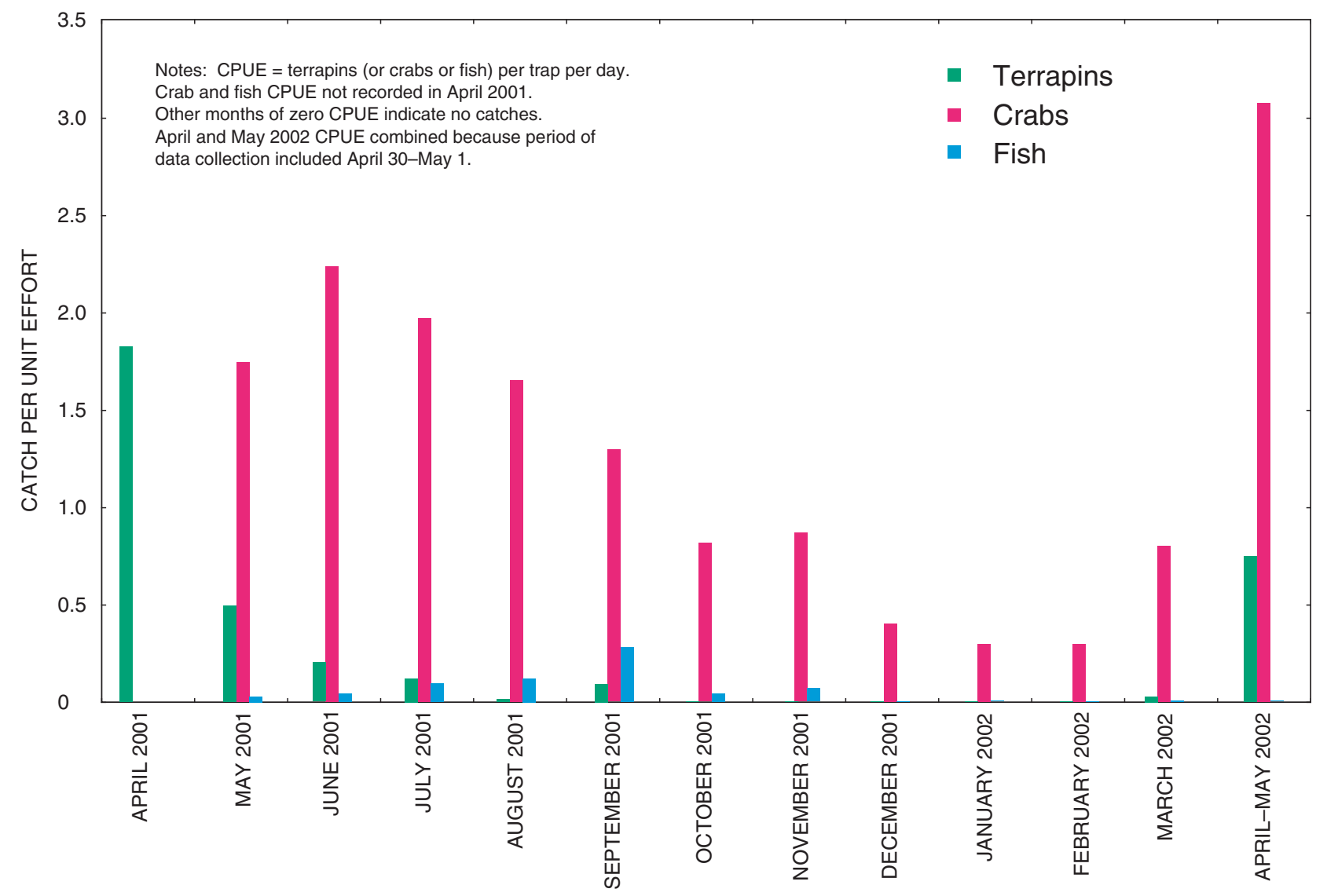

Figure 4. Catch per unit effort (CPUE) of Diamondback terrapins and by-catch at South Deer Island, Texas, April 2001-May 2002.

because they were lost upon capture before all pertinent data could be obtained, and one was not counted because it was too small for sex to be determined.

The most terrapins were captured during AprilMay 2001 and April-May 2002. These months yielded the highest monthly CPUE (fig. 4). The CPUE of terrapins decreased from 1.87 in April 2001 to 0.50 in May 2001 and then to 0.21 in June 2001. The CPUE was zero during October 2001-February 2002 and did not increase substantially until April-May 2002, when it rose to 0.75 . The decrease in CPUE that began in June could have been associated with Tropical Storm Allison, which occurred June 5-9. The storm caused tidal elevations at least 0.9 meter above normal and generated near 100-kilometer-per-hour winds.

Recorded by-catch in crab traps comprised 468 blue crabs, 57 stone crabs, 137 hermit crabs, and 31 fish (species not identified). CPUE for crabs (species combined) and fish also were computed (fig. 4). Terrapin CPUE was positively correlated with crab CPUE and negatively correlated with fish CPUE (fig. 5).

\section{Terrapin Nesting}

Females in southern terrapin ranges emerge from their mainly aquatic environment in search of suitable nest sites in early spring (Carr, 1955), sometimes traveling long distances on land. Terrapins return to the same area to nest each year (Jeyasuria and others, 1994). Unlike sea turtles that nest mainly during the night, Diamondback terrapins nest during the day and night (Burger, 1977; Burger and Montevecchi, 1975). Females often cross salt-marsh grasses to search for nest sites in the sparsely vegetated, sandy substrate of high dunes above high tide (Reid, 1955). In search of a suitable nest site, the female engages in sand sniffing, which is a homing behavior or an attempt to avoid nesting near concentrations of beach-grass rhizomes that penetrate the eggs and cause embryo mortality (Lazell and Auger, 1981). A suitable nest site is sparsely vegetated, gently sloping, and above high tide. Searching for nest sites lasts up to 15 minutes, and a female might test as many 


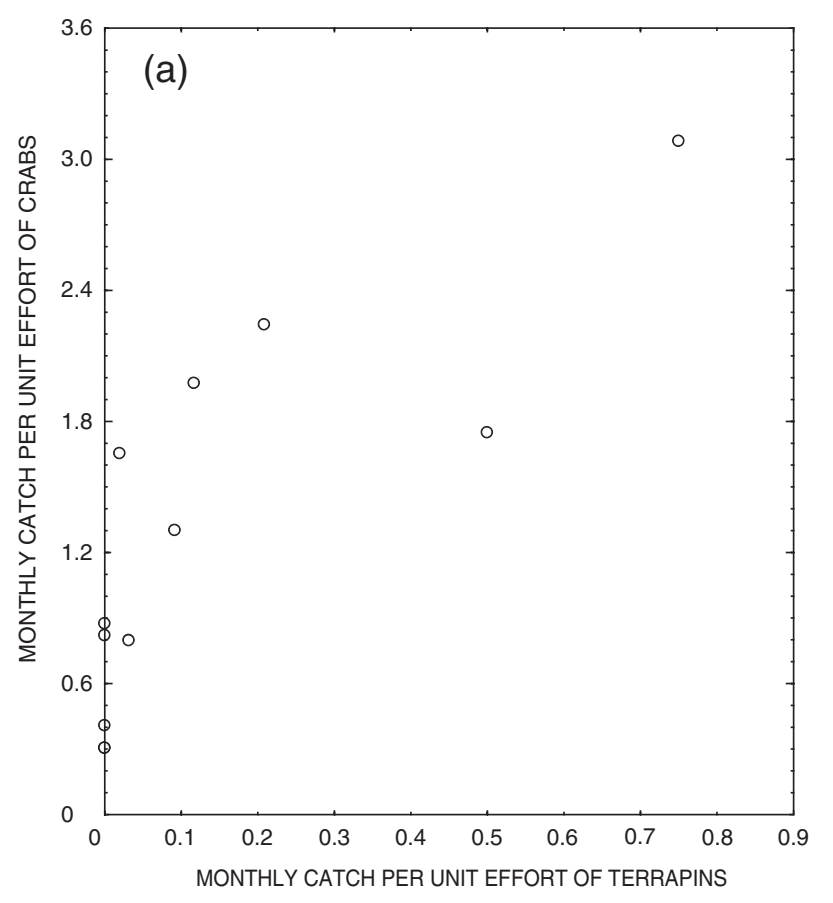

Figure 5. Correlation of monthly catch per unit effort of (a) terrapins and crabs and (b) terrapins and fish at South Deer Island, Texas, April 2001-May 2002.

as 10 locations before nesting, especially if she encounters roots or rocks (Burger, 1977).

Once a suitable nest site has been located, nesting occurs within 20 minutes from start to finish (Burger, 1977; Burger and Montevecchi, 1975; Jeyasuria and others, 1994). Female terrapins face uphill as they construct flask-shaped cavities in low-sloping dunes. Egg cavities typically range from about 10 to 24 centimeters deep and are about 10 centimeters wide (Jeyasuria and others, 1994; Reid, 1955). Females lower their bodies into the excavated nest cavity to deposit a clutch of 4 to 18 eggs. Eggs are elliptical and measure 26 to 36 millimeters long and 16 to 22 millimeters wide (Ernst and Barbour, 1989). After nesting, females may void the cloacal bladder in an attempt to facilitate nest digging, compact the nest substrate, avoid nest predation, camouflage the nest, and add moisture to the eggs (Patterson, 1971). After nesting, the female will cover the entire nest site with sand or shell.

Female terrapins have low reproductive rates, laying a maximum of 39 eggs annually (Roosenburg, 1990). At times, females might store semen as long as 4 years before laying a single clutch of eggs (Barney, 1922). Captive populations have shown greater than $90-$ percent egg fertility (Barney, 1922; Hildebrande, 1929) and attain maximum egg production at 25 years of age

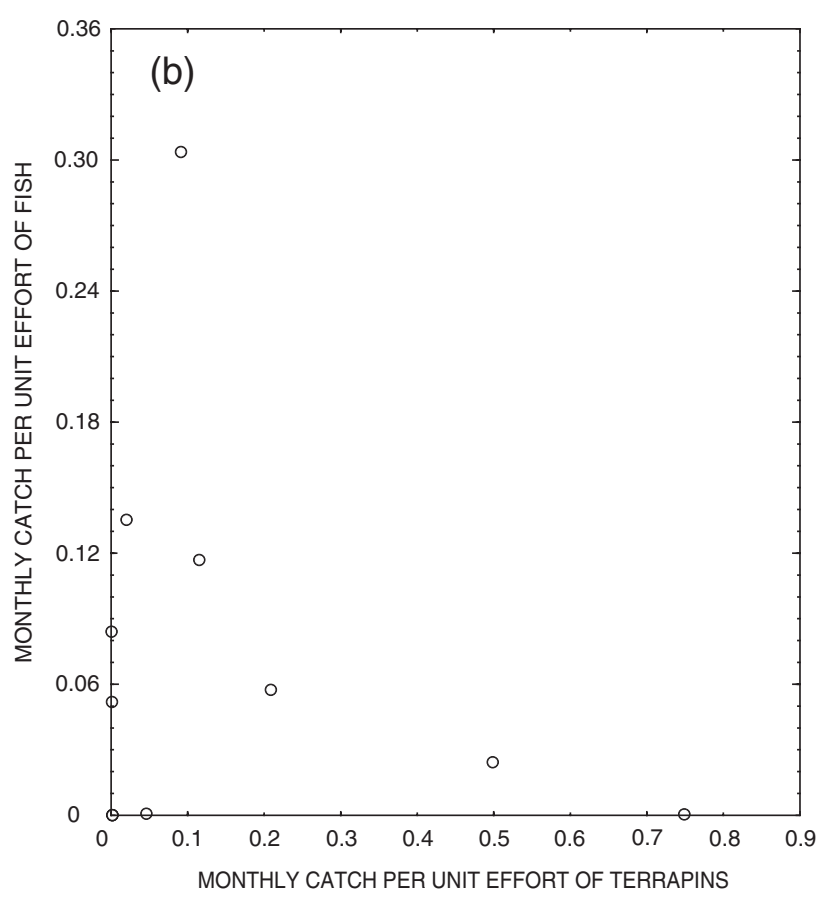

(Barney, 1922). Hatchling emergence usually occurs after 69 days of incubation (Reid, 1955) but might take longer if summer temperatures are below normal (Hay, 1904).

One female terrapin was discovered nesting on a shell beach at the end of April 2001 (fig. 6). The clutch contained seven eggs averaging 3.9 centimeters long and 2.3 centimeters wide (fig. 7 ). The nest cavity was 20 centimeters deep and 12 centimeters wide. Vegetative cover at the nest site was about 50 percent. The nest was located 20 centimeters from vegetation. The closest vegetation was 58 centimeters high, and the distance to water was 5.3 meters. Potential nest predators included laughing gulls and an unidentified species of red ants. No sign of nest depredation was evident through September 2001 despite the presence of a laughing gull nest within 0.70 meter of the terrapin nest. No terrapins were observed nesting during April-May 2002. Only one of seven females palpitated for eggs during April-May 2002 contained eggs.

\section{Terrapin Characteristics}

Biometric data (table 2) collected on terrapins captured showed size dimorphism on the basis of sex (figs. 8-10). Female straight-line carapace length ranged from 14.5 to 20.1 centimeters, and width ranged 


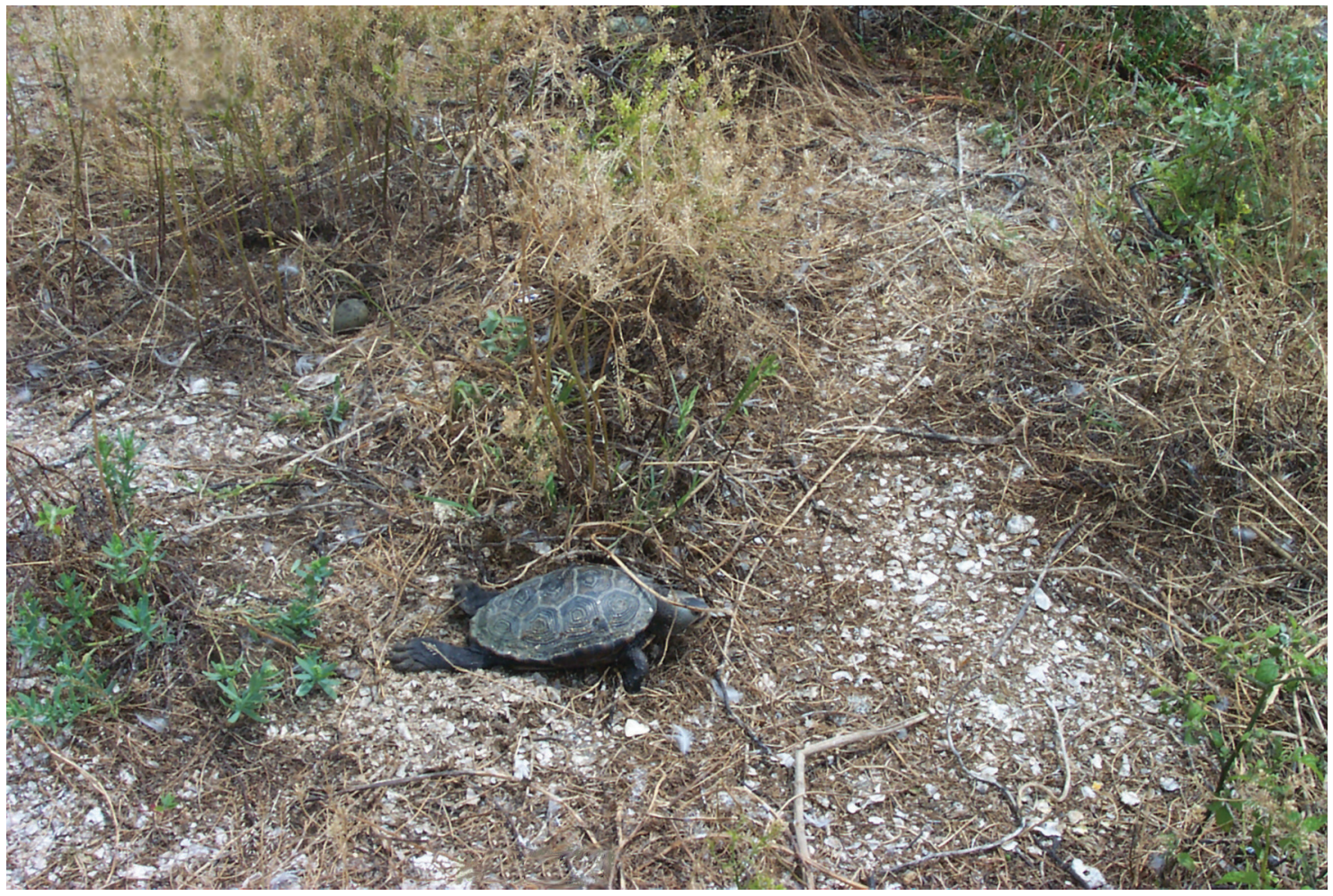

Figure 6. Female Diamondback terrapin covering her nest site on South Deer Island, Texas.

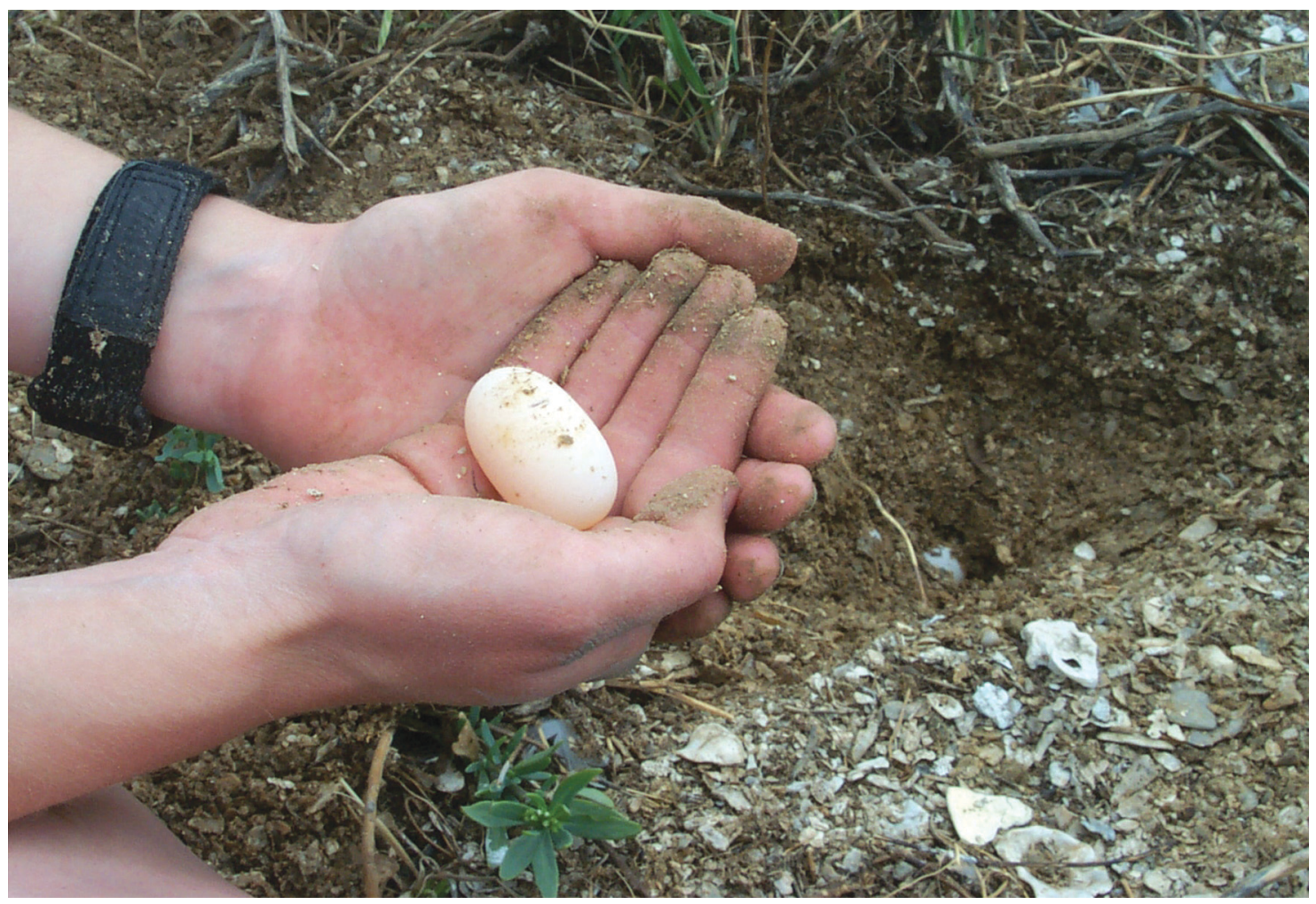

Figure 7. Diamondback terrapin egg from a nest on South Deer Island, Texas. 


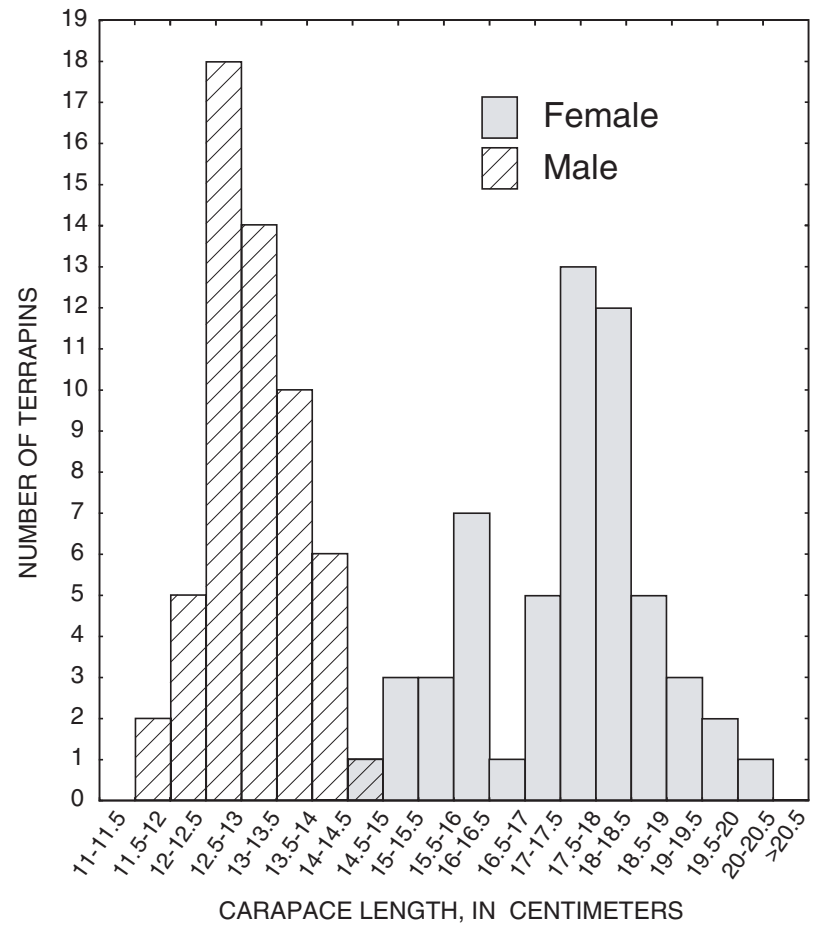

Figure 8. Female and male straight-line carapace lengths of Diamondback terrapins captured at South Deer Island, Texas, April 2001-May 2002.

from 10.9 to 14.6 centimeters; male carapace length ranged from 11.9 to 14.8 centimeters, and width ranged from 8.6 to 11.0 centimeters. Female plastron length ranged from 13.1 to 17.4 centimeters, and width ranged from 6.7 to 9.9 centimeters; male plastron length ranged from 10.3 to 13.7 centimeters, and width ranged from 5.0 to 7.1 centimeters. The median female carapace length was 17.8 centimeters, 1.4 times larger than the median male carapace length, 13.1 centimeters. The median female mass was 1,021 grams, 2.9 times larger than the median male mass, 354 grams.

Size dimorphism also is demonstrated by comparing the condition factor of female terrapins captured with that of males captured. The median condition factor of females was 57.0, and the median condition factor of males was 26.7 (fig. 11).

Intra-specific variation occurred in the coloration and markings of terrapins captured. The faces of terrapins varied from black to gray or blue (fig. 12). On the dorsum of the head, a pale-brown to black diamondshaped pattern usually was pronounced against the speckled design on the head. The diamond-shaped pattern occasionally was marked with black speckles. Some terrapins had light- to dark-brown moustaches, and others had a yellow beak. The carapace varied from light brown to black (fig. 13), and the plastron varied from pale yellow to dark brown or black (fig. 14). The periphery of the plastron of some terrapins was orange. The color of the legs varied from pale gray to black, and the markings on the skin varied from small specks to large dots.

Terrapins were checked for anomalies, which included lesions, deformities, barnacles, and algae. The highest frequency of lesions-50 percent-occurred among terrapins captured in March 2002 (fig. 15). Both lesions and deformities were more common among males than females. Lesions were found on 15 percent of males and 7 percent of females, and deformities were observed on 5 percent of males and none on females.

Both sexes had similar frequencies of occurrence of barnacles and similar frequencies of occurrence of algae (fig. 16). Barnacles were found on 40 percent of females and on 32 percent of males. Algae was present mainly on the carapace of most terrapins. Algae was found on 89 percent of females and 92 percent of males. Of the algae species attached to the carapace of terrapins, Oscillatoria sp., Anacystis sp., and Schizothrix sp. were the most common (40 percent, 20 percent, and 20 percent, respectively). Other algae species attached included Porphyrosiphon sp. and Enteromorpha lingulata (13 percent and 7 percent, respectively).

Eleven terrapins captured during April-May 2002 also were checked for scute abnormalities. Five had scute abnormalities, which included split or partially split vertebral scutes, additional scutes at the base of the gular scute, a reduced number of marginal scutes, or split cervical scutes.

\section{Terrapin Habitat}

Terrapin habitat at South Deer Island consists of shell areas, salt marshes, and oyster-shell reefs-the same types of habitat documented in the previous studies noted.

The maximum water temperature manually recorded during terrapin collection periods in JulySeptember 2001 and March-May 2002 (the periods when environmental data were collected and terrapins were captured) ranged from 22.4 to 36.3 degrees Celsius (table 3, at end of report); the maximum salinity ranged from 2,030 to 3,320 milligrams per liter; the maximum dissolved oxygen ranged from 6.9 to 11 milligrams per liter; the maximum conductivity ranged 

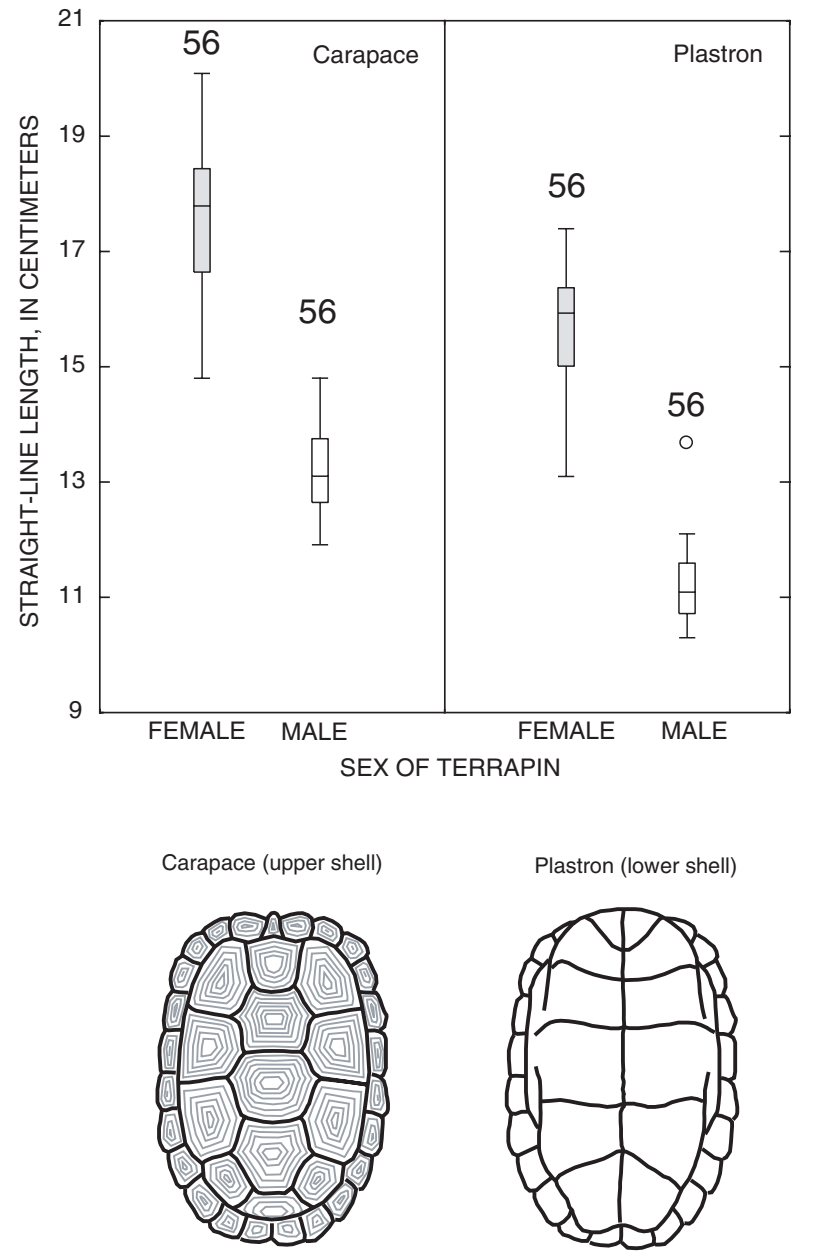

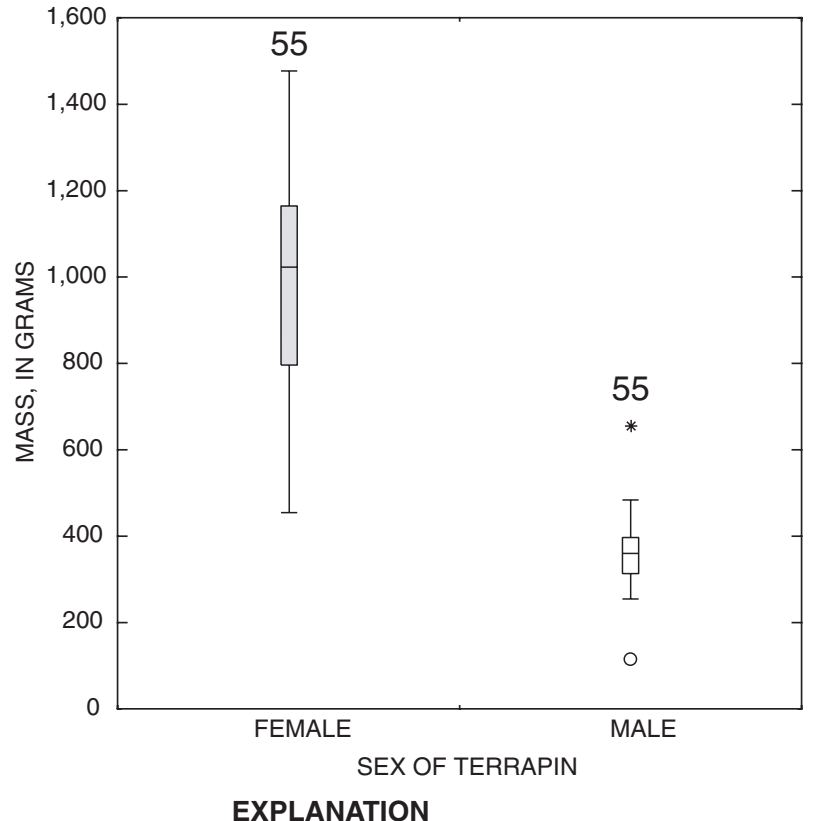

55 Number of samples

* Data value greater than 3.0 times the IQR outside the box

○ Data value 1.5 to 3.0 times the IQR outside the box

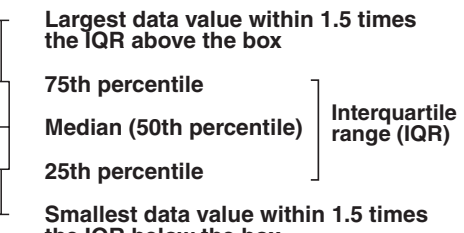

Smallest data value within 1.5 times

Figure 9. Size data from Diamondback terrapins captured at South Deer Island, Texas, April 2001-May 2002.

from 31,500 to 51,200 microsiemens per centimeter at 25 degrees Celsius; and the maximum $\mathrm{pH}$ ranged from 7.9 to 9.0 .

The maximum water temperature recorded manually at South Deer Island and recorded by National Ocean Service data logger in Galveston Channel during terrapin collection periods, July 2001-May 2002, is illustrated in figure 17. Neither maximum air temperature nor maximum water temperature was correlated with terrapin CPUE.

Dominant vegetation or substrate associated with terrapin habitat included saltwort, slender seapurslane, seabeach orache, shell, and woody debris. Table 4 (at end of report) shows the percentage of vegetation species or substrate equal to or greater than 20 percent along transects at locations shown in figure 2.

Comparison of 1930 and 1958 aerial photographs of South Deer Island with a 1995 digital orthophoto (fig. 18) shows that the northeastern shore of the island is eroding over time and that the open-water lagoon is a relatively recent (post-1958) feature. The area of the island decreased about 33 percent between 1930 and 1995, which has resulted in a reduction in the length, and therefore the amount, of shoreline habitat. Since 1958, the formation of the lagoon has increased the amount of shoreline habitat, but the moist lagoon habitat is unsuitable for nesting because of the potential for inundation.

\section{SUGGESTIONS FOR FURTHER STUDY}

One suggestion for future terrapin study is to identify the current range of terrapins in Texas. The southernmost range of terrapins has been researched as far south as the Nueces River and Nueces Bay, although in the mid-1980s, sightings occurred about 


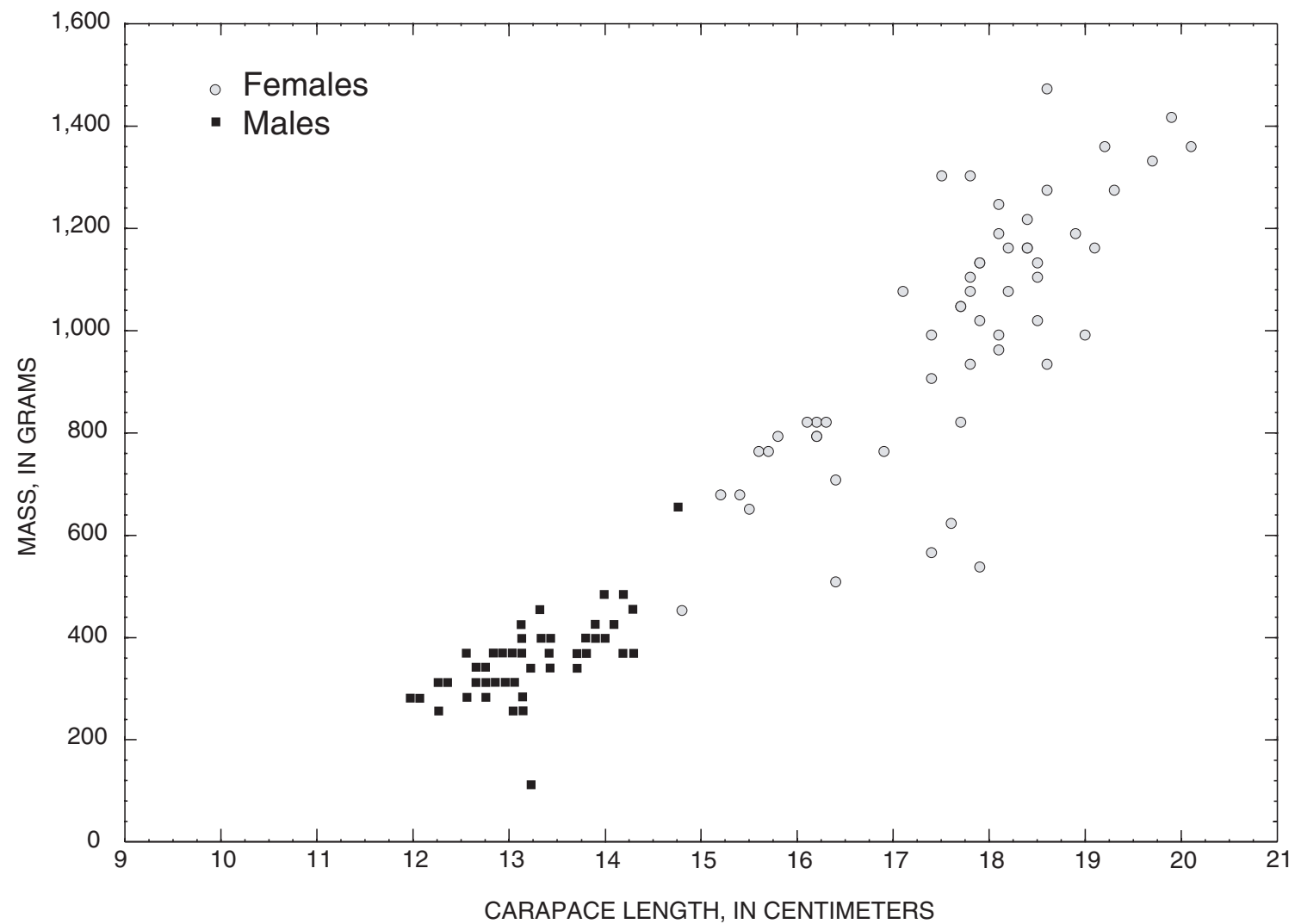

Figure 10. Correlation of straight-line carapace length with mass of Diamondback terrapins captured at South Deer Island, Texas, April 2001-May 2002.

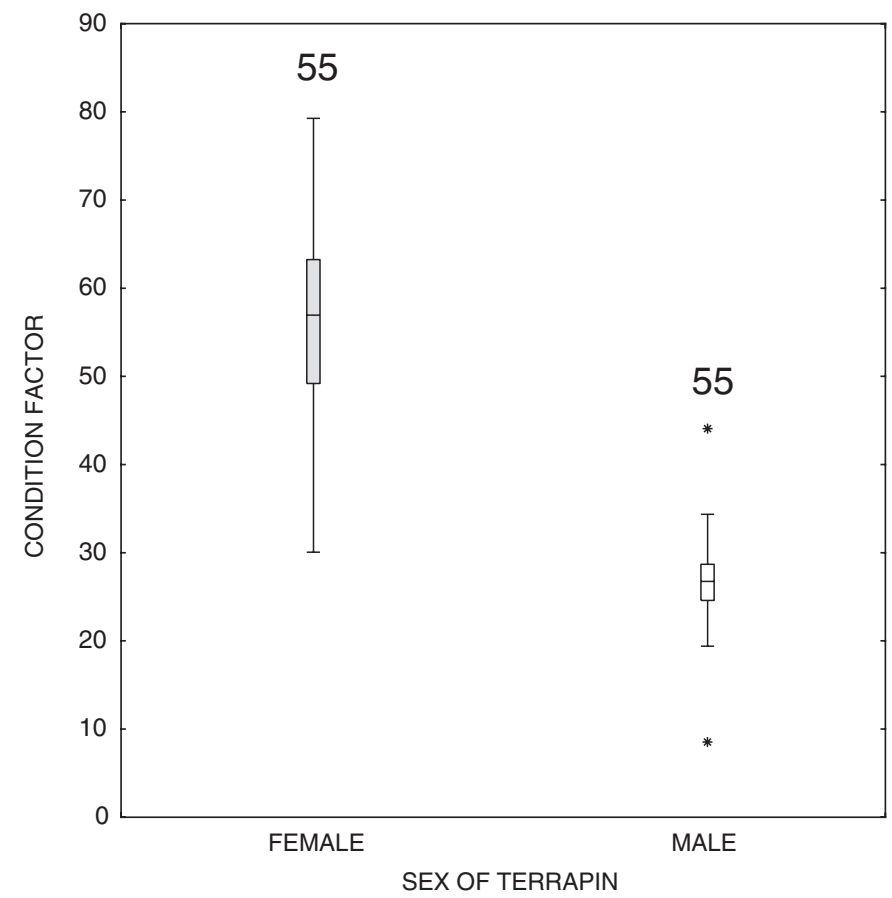

\section{EXPLANATION}

55 Number of samples

* Data value greater than 3.0 times the IQR outside the box

T Largest data value within 1.5 times the IQR above the box

75th percentile Median (50th percentile) $\quad \begin{aligned} & \text { Interquartile } \\ & \text { range (IQR) }\end{aligned}$ 25th percentile

Smallest data value within 1.5 times the IQR below the box

Figure 11. Condition factor of female and male Diamondback terrapins captured at South Deer Island, Texas, April 2001-May 2002. 


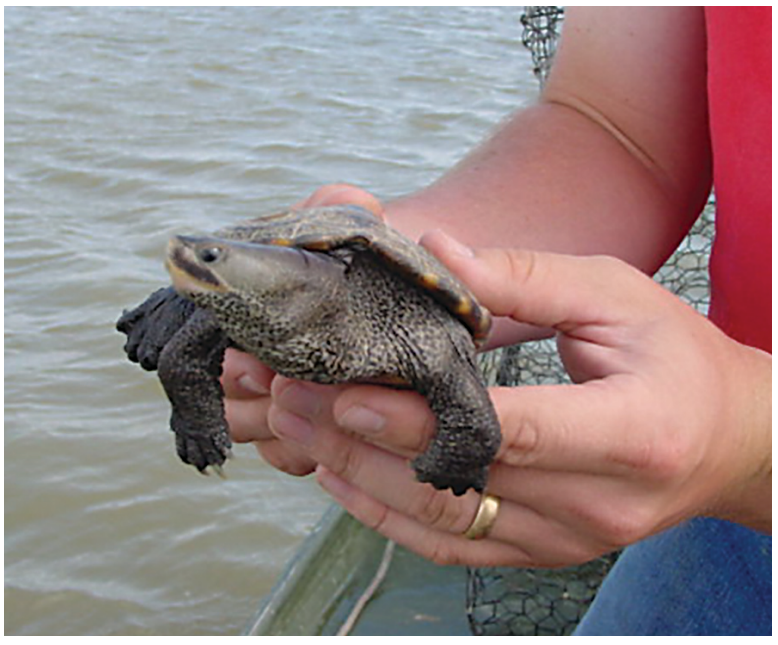

Terrapin with dark moustache and dark-gray to black skin.

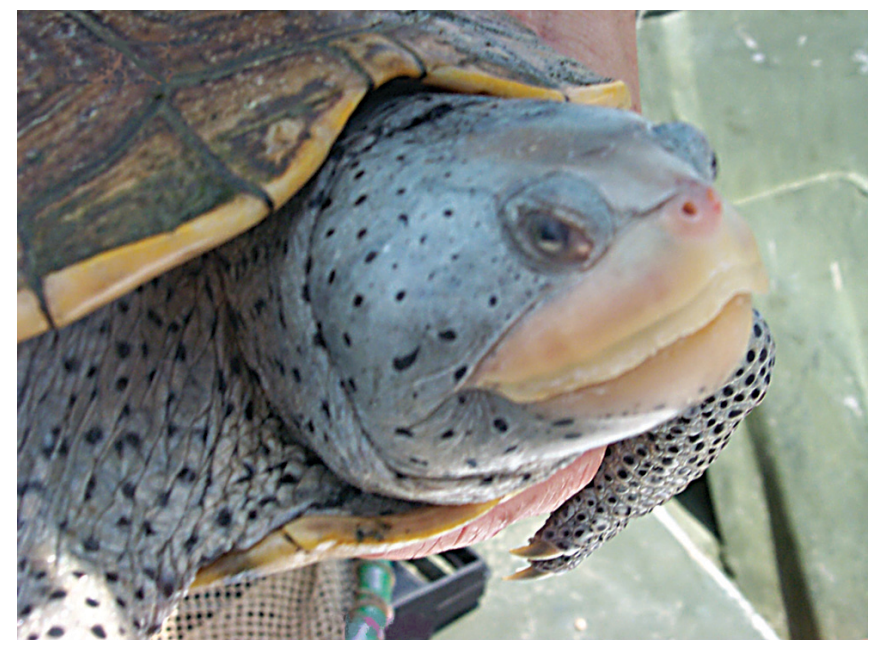

Terrapin without moustache and blue to light-gray skin.

Figure 12. Variation in color and markings among Diamondback terrapins captured at South Deer Island, Texas, April 2001-May 2002.

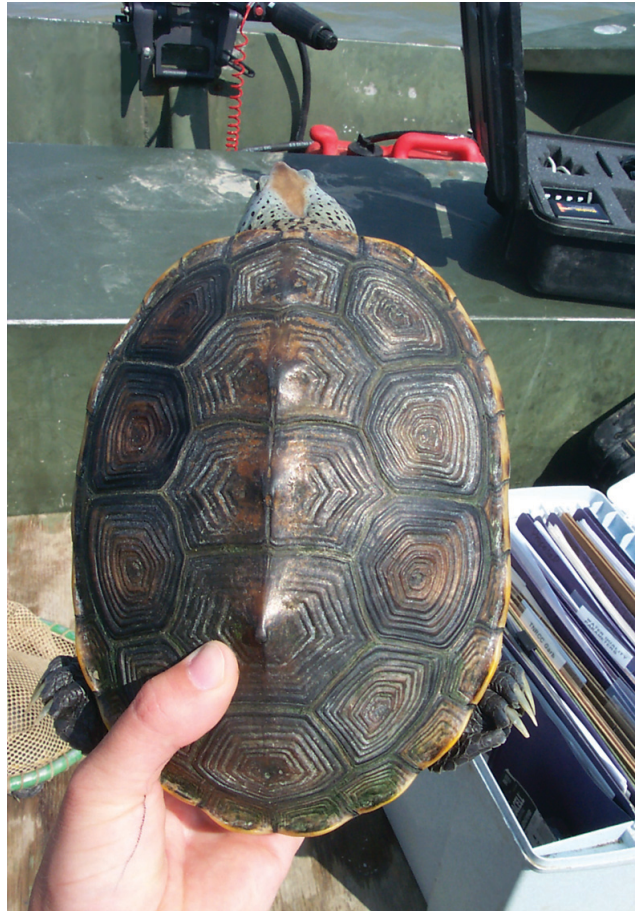

Terrapin with light-brown carapace.

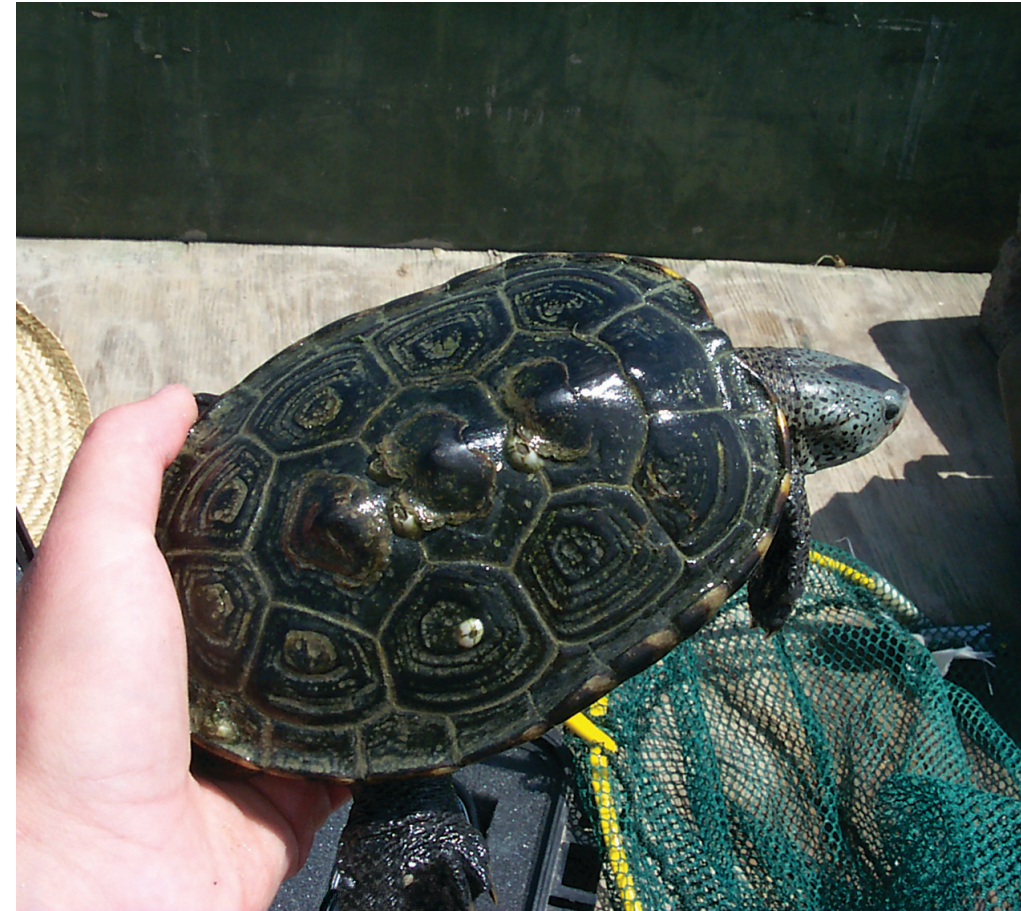

Terrapin with black carapace.

Figure 13. Variation in carapace color among Diamondback terrapins captured at South Deer Island, Texas, April 2001-May 2002. 


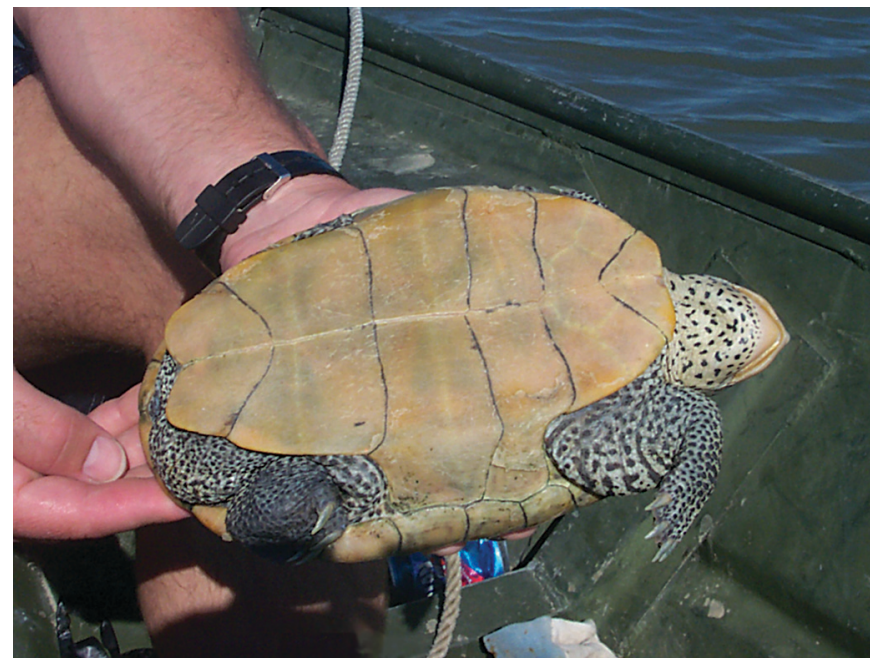

Terrapin with pale-yellow plastron.

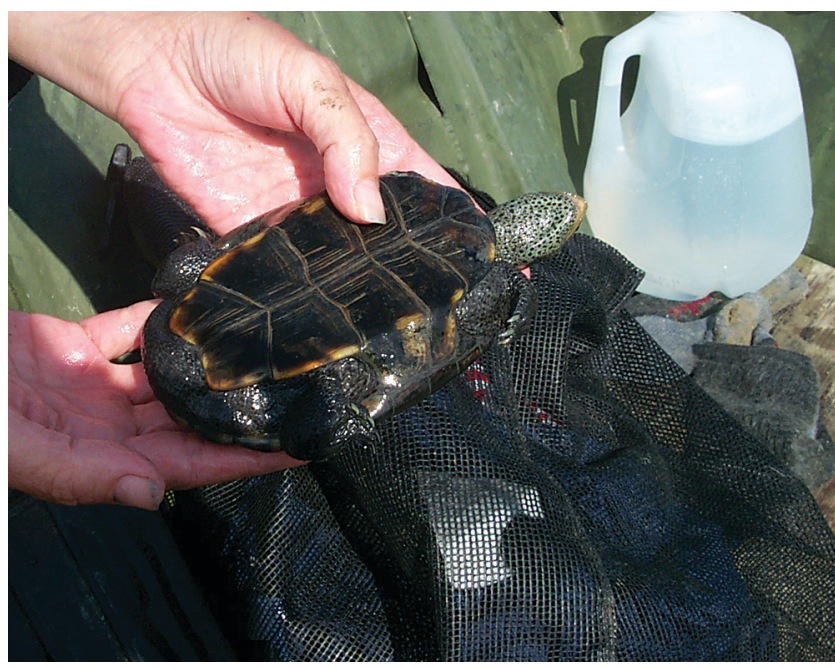

Terrapin with black plastron and an orange fringe.

Figure 14. Variation in plastron color among Diamondback terrapins captured at South Deer Island, Texas, April 2001-May 2002.

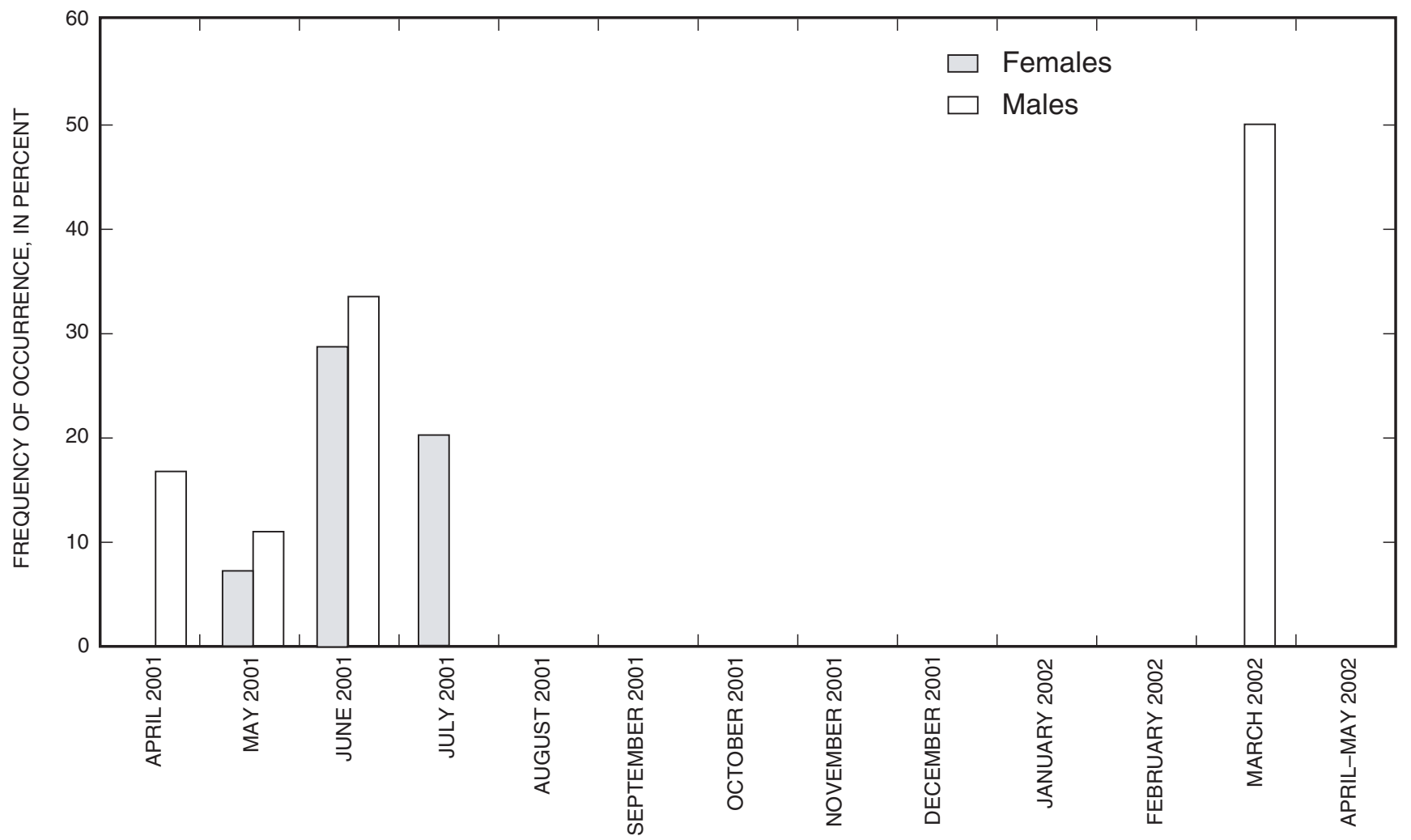

Figure 15. Frequency of occurrence of female and male Diamondback terrapins with lesions captured at South Deer Island, Texas, April 2001-May 2002. 


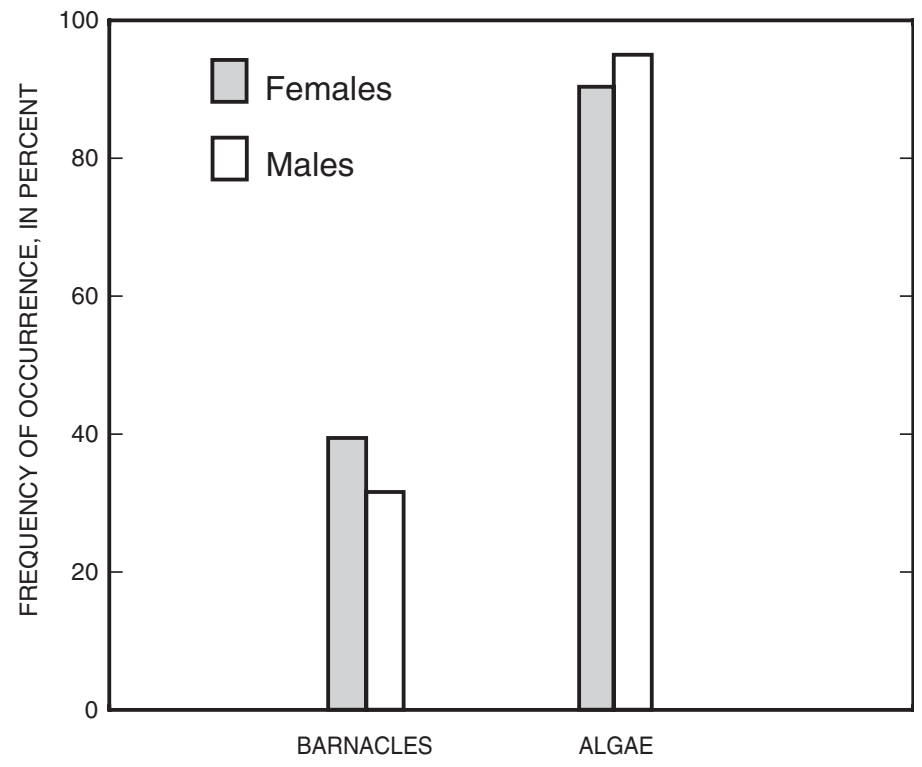

Figure 16. Frequency of occurrence of female and male Diamondback terrapins with barnacles and algae captured at South Deer Island, Texas, April 2001-May 2002.

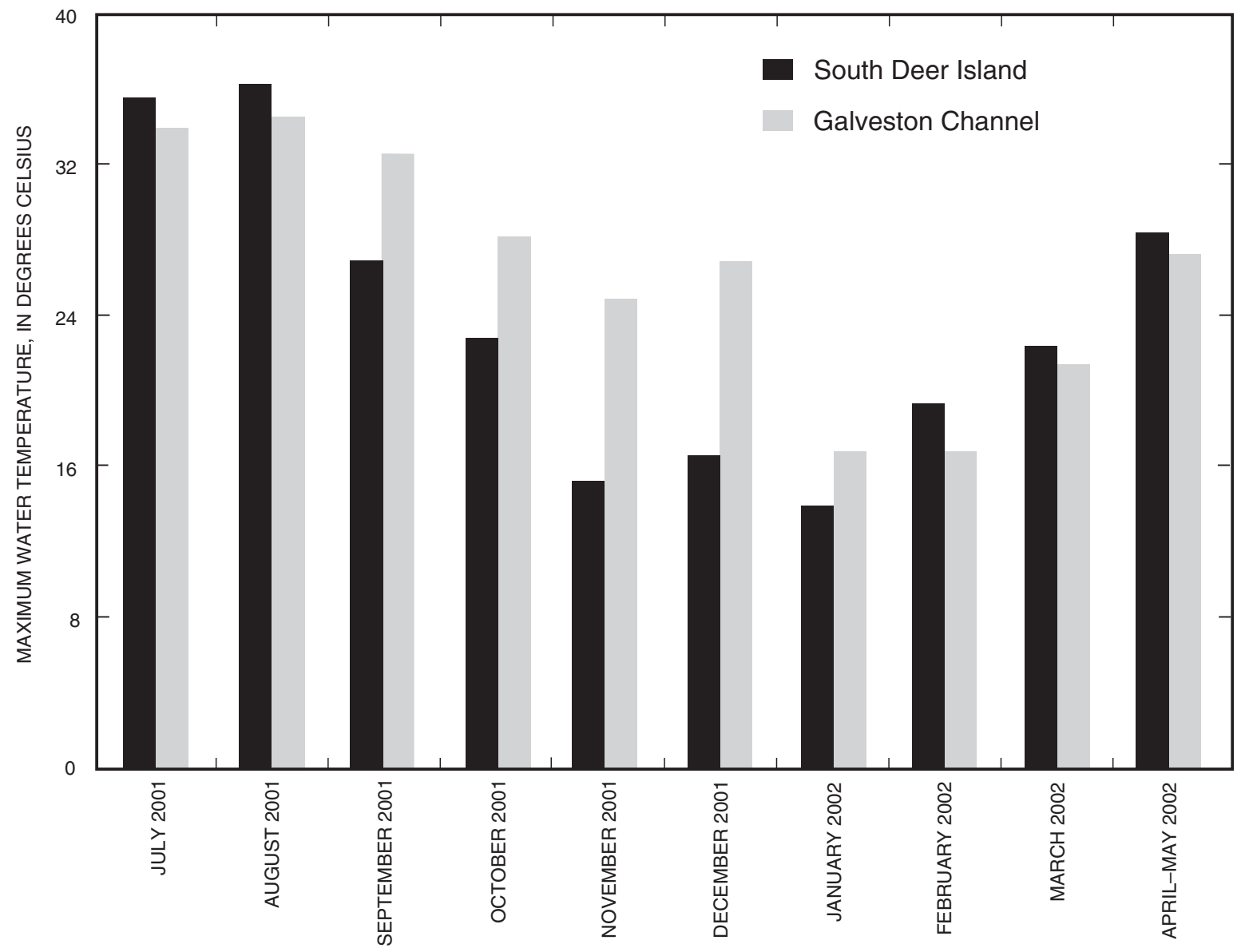

Figure 17. Maximum water temperature recorded manually at South Deer Island and recorded by National Ocean Service data logger in Galveston Channel during terrapin collection periods, July 2001-May 2002. 
(a) 1930

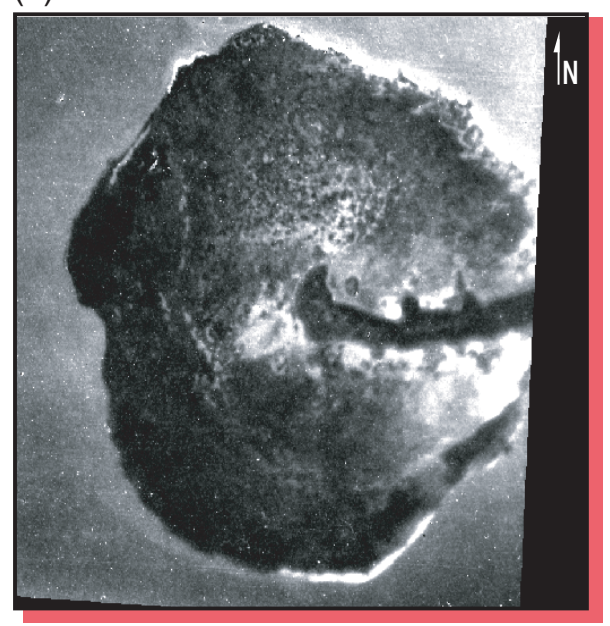

(b) 1958

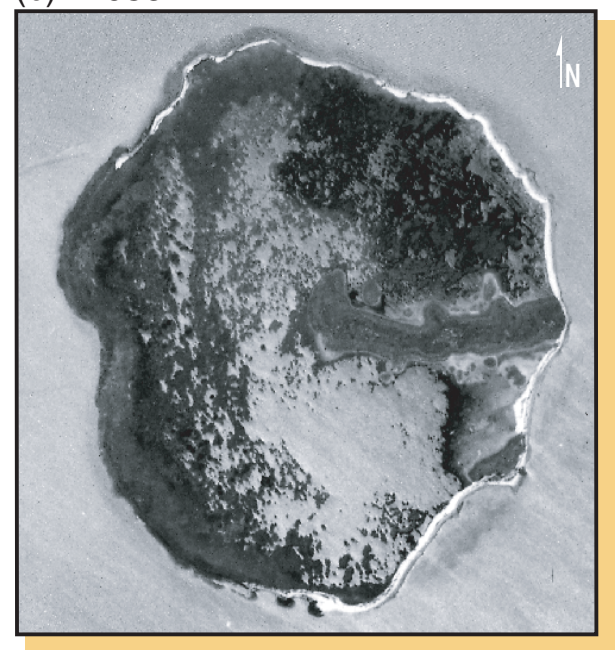

(c) 1995

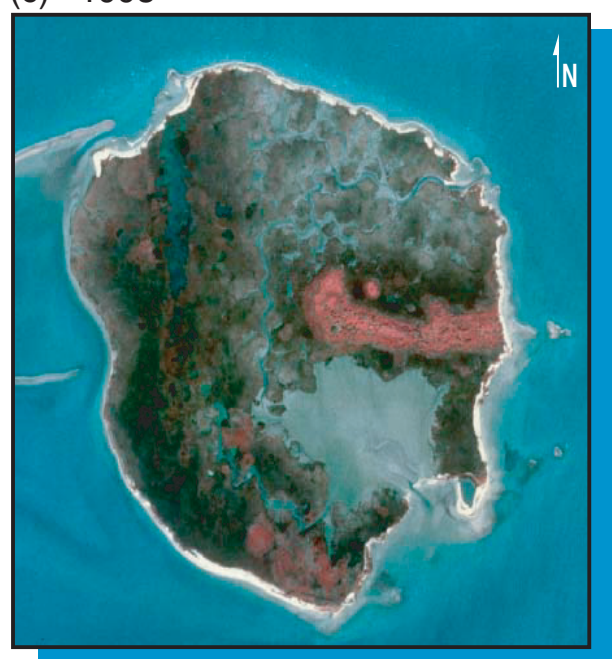

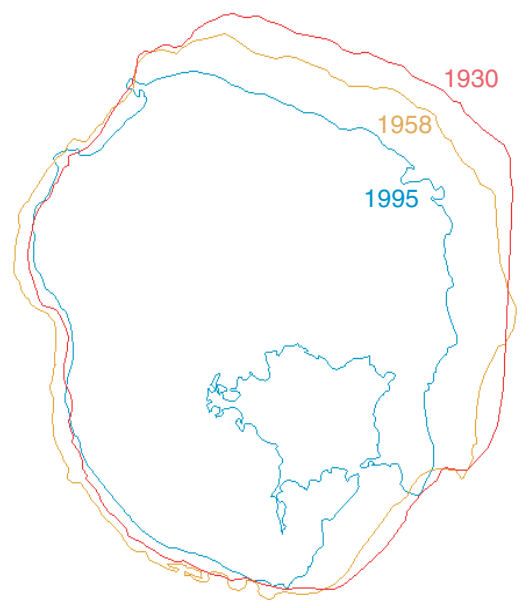

Boundary of South Deer Island, 1930, 1958, and 1995.

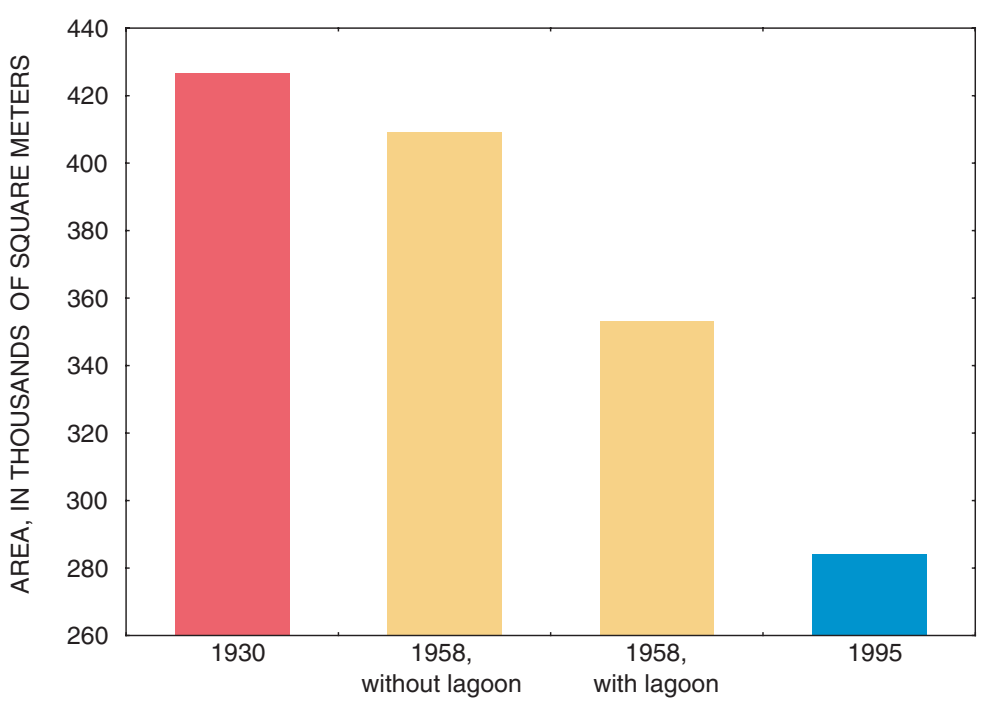

Surface area of South Deer Island, 1930, 1958, and 1995.

Figure 18. Historical photographs (a, b) and digital orthophoto (c) of South Deer Island, Texas, from 1930, 1958, and 1995 (Texas Natural Resources Information System). 
30 kilometers south of Corpus Christi in Baffin Bay and near Pita Island in the northern part of Laguna Madre. Coastal areas with characteristic terrapin habitat (shell areas, salt marshes, oyster-shell reefs) would be logical places to monitor.

Another recommendation for future study is to conduct long-term mark-and-recapture studies in areas of terrapin abundance. Data obtained from long-term studies in Texas then could be compared to long-term data collected in South Carolina, where a previous mark-and-recapture study was conducted (Roosenburg, 1990). Population structures and life histories could be compared between two subspecies in two different climates and ranges.

Another suggestion for terrapin research in Texas is to further define terrapin nesting habitat and to document additional nest sites. Because terrapins practice nest-site fidelity, changes in nest-site preferences over time might indicate areas that are prone to habitat disturbance. Also, Texas nests could be compared to East Coast terrapin nests to indicate differences among subspecies and their adaptability to various climates and habitat.

A final suggestion is to conduct tracking studies to determine migratory patterns of terrapins in Texas. The data could help to identify the factors that define terrapin habitat throughout the seasons of the year.

\section{SUMMARY}

The USGS, in cooperation with the U.S. Fish and Wildlife Service, conducted occurrence surveys and nesting and basking surveys at South Deer Island, a privately owned 0.3-square-kilometer island in Galveston Bay 1.6 kilometers north of Galveston, Tex. Occurrence surveys were conducted each month during April 2001May 2002 along the southern shore of the island and along the shore of a lagoon on the island during the same period, excluding November-December 2001. Nesting and basking surveys were conducted along the southern shore of the island each month during April 2001-May 2002, excluding November-December.

Two methods to collect terrapins were used in the occurrence surveys: Along the southern shore of the island, terrapins were captured in crab traps placed in shallow water offshore; in the lagoon on the island, terrapins were captured by hand while walking along the shore. In the nesting and basking surveys, areas of the island with continuous patches of exposed shell typically were checked twice a day for nesting and basking terrapins, except during the last 2 months of the study, when more intensive monitoring was done because the single nest found the previous year was found at the end of April.

One-hundred thirty-five terrapins were captured in occurrence and nesting and basking surveys at South Deer Island. Of the 135 captured, 116 were unique individuals, 19 were recaptures, one of which was recaptured three times (thus 16 unique individuals recaptured). The occurrence surveys resulted in 119 terrapins captured in crab traps and nine captured by hand around the lagoon. The nesting and basking surveys yielded seven terrapins. Only one was nesting, although the nest is believed to be the first documented terrapin nest found in Texas. The nesting female was discovered on a shell beach at the end of April 2001. The clutch contained seven eggs. Three terrapins were captured swimming near shell beaches, and three more were captured basking on shell beaches. Fifty-six females and 56 males (unique individuals) were captured in the surveys. (Four terrapins captured were not counted because they were lost upon capture or sex could not be determined.) The most terrapins were captured during April-May 2001 and April-May 2002. These months yielded the highest monthly number of terrapins (excluding recaptures) per trap-day, or catch per unit effort (CPUE). Neither maximum air temperature nor maximum water temperature could be correlated with terrapin CPUE.

Biometric data collected on terrapins captured showed size dimorphism on the basis of sex. The median female straight-line carapace length was 17.8 centimeters, 1.4 times larger than the median male carapace length, 13.1 centimeters. The median female mass was 1,021 grams, 2.9 times larger than the median male mass, 354 grams.

Intra-specific variation occurred in the colorations and markings of terrapins captured. The faces of terrapins varied from black to gray or blue. The carapace varied from light brown to black, and the plastron varied from pale yellow to dark brown or black. On the dorsum of the head, a pale-brown to black diamondshaped pattern usually was pronounced against the speckled design on the head.

Anomalies-lesions, deformities, barnacles, and algae-were common among terrapins captured. Both lesions and deformities were more common among males than females. Lesions were found on 15 percent of males and 7 percent of females, and deformities were observed on 5 percent of males, none on females. 
Barnacles were found on 40 percent of females and 32 percent of males. Algae was found on 89 percent of females and 92 percent of males, mainly on the carapace.

Dominant vegetation or substrate associated with terrapin habitat included saltwort, slender seapurslane, seabeach orache, shell, and woody debris.

\section{REFERENCES CITED}

Babcock, H.L., 1926, The Diamondback terrapin in Massachusetts: Copeia 1926, p. 101-105.

Barney, R.L., 1922, Further notes on the natural history and artificial propagation of the Diamond-back terrapin: Bulletin of the Bureau of Fisheries, v. 27, p. 91-111.

Bishop, J.M., 1983, Incidental capture of Diamondback terrapin by crab pots: Estuaries, v. 6, p. 426-430.

Burger, J., 1977, Determinants of hatching success in Diamondback terrapin, Malaclemys terrapin: American Midland Naturalist, v. 97, no. 2, p. 444-464.

Burger, J.D., and Montevecchi, W.A., 1975, Nest site selection in the terrapin, Malaclemys terrapin: Copeia 1975, no. 1, p. 113-119.

Cagle, F.R., 1952, A Louisiana terrapin population (Malaclemys): Copeia 1952, no. 2, p. 74-79.

Carr, A.F., 1955, Handbook of turtles-The turtles of the United States, Canada, and Baja California: Ithaca, N.Y., Comstock Publishing Associates, p. 162-185.

Coker, R.E., 1920, The Diamondback terrapin-Past, present, and future: Scientific Monthly, p. 171-186.

Ernst, C.H., and Barbour, R.W., 1989, Turtles of the world: Washington, D.C., Smithsonian Institution Press, p. 225-226.

Gunter, G., 1981, Status of turtles on the Mississippi coast, USA: Gulf Research Reports, v. 7, no. 1, p. 89-92.

Hay, W.P., 1904, A revision of Malaclemmys, a genus of turtles: Bulletin of the Bureau of Fisheries, v. 24, p. 3-19.

Hildebrande, S.F., 1929, Review of experiments on artificial culture of Diamond-back terrapin: Bulletin of the Bureau of Fisheries, v. 45, p. 25-70.

1933, Hybridizing Diamond-back terrapins: Journal of Heredity, v. 113, p. 231-238.

Huffman, J., 1997, Preliminary study of Diamondback terrapin (Malaclemys terrapin) populations in West Bay, Galveston, Texas: University of Houston-Clear Lake, Master's thesis.

Jeyasuria, P., Roosenburg, W.M., and Place, A.R., 1994, Role of $\mathrm{P}-450$ aromatase in sex determination of the Diamondback terrapin, Malaclemys terrapin: Journal of Experimental Zoology, v. 270, no. 1, p. 95-111.
Lazell, J.D., and Auger, P.J., 1981, Predation of Diamondback terrapin (Malaclemys terrapin) by dune grass (Ammophila breviligulata): Copeia 1981, p. 723-724.

Moring, J.B., and Setser, Rita, 2000, Historical changes in streamflows, channel morphology, and riparian vegetation of the Rio Grande downstream of Brownsville, Texas: U.S. Geological Survey Fact Sheet FS-074-00, $6 \mathrm{p}$.

Patterson, R., 1971, The role of urination in egg predator defense in the desert tortoise (Gopherus agassizi): Herpetologica 27, p. 197-199.

Reid, G.K., Jr., 1955, Reproduction and development in the northern Diamondback terrapin, Malaclemys terrapin terrapin: Copeia 1955, p. 310-311.

Roosenburg, W.M., 1990, The Diamondback terrapin: Population dynamics, habitat requirements, and opportunities for conservation, in Mihursky, J.A., and Chaney, A., eds., New Perspectives in the Chesapeake System-A Research and Management Partnership, Baltimore, Md., Dec. 4-6, 1990, Proceedings: Chesapeake Research Consortium Publication No. 137, p. 227-234.

Scribner, K.T., Morreale, S.J., Smith, M.H., and Gibbons, J.W., 1995, Factors contributing to temporal and age-specific genetic variation in the freshwater turtle Trachemys scripta: Copeia 1995, no. 4, p. 970-977.

Seigel, R.A., and Gibbons, J.W., 1995, Workshop on the ecology, status, and management of the Diamondback terrapin (Malaclemys terrapin), Savannah River Ecology Laboratory, 2 August 1994-Final results and recommendations: Chelonian Conservation and Biology, v. 1, no. 3, p. 240-243.

Smith, H.M., and Smith R.B., 1979, Synopsis of the herpetofauna of Mexico-Guide to Mexican turtles, bibliographic addendum III: John Johnson, p. 524-527.

Wood, R.C., and Herlands, R., 1995, Terrapins, tires, and traps-Conservation of the northern Diamondback terrapin (Malaclemys terrapin terrapin) on the Cape May Peninsula, New Jersey, USA, in Devaux, B., ed., International Congress of Chelonian Conservation, Gonfaron, France, July 6-10, 1995, Proceedings: SOPTOM, p. 254-256.

1997, Turtles and tires-The impact of roadkills on northern Diamondback terrapin, Malaclemys terrapin terrapin, populations on the Cape May Peninsula, Southern New Jersey, USA, in Van Abbema, ed., Conservation, Restoration, and Management of Tortoises and Turtles-An International Conference, July 11-16, 1993, Proceedings: New York Turtle and Tortoise Society, p. 46-53. 
Table 2. Summary of terrapin capture and biometric data, South Deer Island, Texas, April 2001-May 2002

[cm, centimeters; --, no data]

\begin{tabular}{|c|c|c|c|c|c|c|c|c|c|c|c|c|c|c|c|c|c|}
\hline \multirow{4}{*}{$\begin{array}{c}\text { Num- } \\
\text { ber }\end{array}$} & \multirow{4}{*}{ Date } & \multicolumn{6}{|c|}{ Capture data } & \multicolumn{10}{|c|}{ Biometric data } \\
\hline & & \multicolumn{3}{|c|}{ Survey type } & \multirow{3}{*}{$\begin{array}{l}\text { Recap- } \\
\text { tured }\end{array}$} & \multirow{2}{*}{\multicolumn{2}{|c|}{$\begin{array}{c}\text { Location } \\
\text { (decimal degrees) }\end{array}$}} & \multirow{2}{*}{\multicolumn{2}{|c|}{$\begin{array}{l}\text { Straight-line } \\
\text { carapace size }\end{array}$}} & \multirow{2}{*}{\multicolumn{2}{|c|}{$\begin{array}{l}\text { Straight-line } \\
\text { plastron size }\end{array}$}} & \multirow{3}{*}{$\begin{array}{c}\text { Mass } \\
\text { (grams) }\end{array}$} & \multirow{3}{*}{ Sex } & \multicolumn{4}{|c|}{ Anomalies } \\
\hline & & \multicolumn{2}{|c|}{ Occurrence } & \multirow{2}{*}{$\begin{array}{l}\text { Nesting } \\
\text { and } \\
\text { basking }\end{array}$} & & & & & & & & & & & & & \\
\hline & & $\begin{array}{l}\text { Crab } \\
\text { trap }\end{array}$ & $\begin{array}{c}\text { La- } \\
\text { goon }\end{array}$ & & & Latitude & Longitude & $\begin{array}{l}\text { Length } \\
(\mathrm{cm})\end{array}$ & $\begin{array}{l}\text { Width } \\
\text { (cm) }\end{array}$ & $\begin{array}{l}\text { Length } \\
\text { (cm) }\end{array}$ & $\begin{array}{l}\text { Width } \\
\text { (cm) }\end{array}$ & & & $\begin{array}{c}\text { Bar- } \\
\text { nacles }\end{array}$ & Algae & $\begin{array}{l}\text { Le- } \\
\text { sions }\end{array}$ & $\begin{array}{l}\text { Deform- } \\
\text { ities }\end{array}$ \\
\hline 1 & $4 / 18 / 2001$ & $\checkmark$ & & & & 291609.81 & 945451.01 & 12.6 & 9.4 & 11.6 & 5.8 & 340.2 & male & no & no & no & no \\
\hline 2 & $4 / 18 / 2001$ & $\checkmark$ & & & & 291607.38 & 945442.91 & 17.7 & 13 & 15.9 & 8.6 & $1,048.95$ & female & yes & no & no & no \\
\hline 3 & $4 / 18 / 2001$ & $\checkmark$ & & & & 291611.2 & 945435.42 & 17.5 & 13.1 & 15.4 & 8.2 & $1,304.1$ & female & yes & no & no & no \\
\hline 4 & $4 / 18 / 2001$ & $\checkmark$ & & & & 291611.2 & 945435.42 & 17.9 & 12.8 & 16.2 & 8.1 & $1,020.6$ & female & no & no & no & no \\
\hline 5 & $4 / 18 / 2001$ & $\checkmark$ & & & & 291613.27 & 945431.36 & 16.4 & 12.1 & 14.6 & 7.9 & 510.3 & female & no & no & no & no \\
\hline 6 & $4 / 18 / 2001$ & $\checkmark$ & & & & 291619.30 & 945453.20 & 19 & 13.9 & 16.8 & 8.9 & 992.25 & female & yes & no & no & no \\
\hline 7 & $4 / 18 / 2001$ & $\checkmark$ & & & & 291613.93 & 945452.79 & 15.6 & 11.6 & 14.8 & 8 & 765.45 & female & no & yes & no & no \\
\hline 8 & $4 / 18 / 2001$ & $\checkmark$ & & & & 291613.15 & 945432.07 & 17.6 & 13 & 16.3 & 7.9 & 623.7 & female & no & yes & no & no \\
\hline 9 & $4 / 18 / 2001$ & $\checkmark$ & & & & 291613.15 & 945432.07 & 15.8 & 11.8 & 14.6 & 7.6 & 793.8 & female & no & yes & no & no \\
\hline 10 & $4 / 18 / 2001$ & $\checkmark$ & & & & 291630.80 & 945449.76 & 13.6 & 9.7 & 12 & 5.6 & -- & male & no & no & no & no \\
\hline 11 & $4 / 18 / 2001$ & $\checkmark$ & & & & 291630.80 & 945449.76 & 17.8 & 12.8 & 16.4 & 8.4 & -- & female & no & yes & no & no \\
\hline 12 & $4 / 19 / 2001$ & $\checkmark$ & & & & 291611.61 & 945435.57 & 17.4 & 12.8 & 15.5 & 8.2 & 907.2 & female & yes & yes & no & no \\
\hline 13 & $4 / 19 / 2001$ & $\checkmark$ & & & & 291619.30 & 945429.58 & 12.7 & 9.7 & 11.1 & 5.9 & 340.2 & male & yes & yes & no & no \\
\hline 14 & $4 / 19 / 2001$ & $\checkmark$ & & & & 291619.30 & 945429.58 & 12.9 & 9.6 & 11.1 & 5.6 & 311.85 & male & no & no & no & no \\
\hline 15 & $4 / 19 / 2001$ & $\checkmark$ & & & & 291630.87 & 945449.27 & 13.9 & 10.1 & 11.6 & 5.9 & 396.9 & male & no & yes & no & no \\
\hline 16 & $4 / 19 / 2001$ & $\checkmark$ & & & & 291614.14 & 945452.04 & 18.5 & 13.3 & 16.8 & 8.4 & $1,020.6$ & female & yes & yes & no & no \\
\hline 17 & $4 / 19 / 2001$ & $\checkmark$ & & & & 291614.14 & 945452.04 & 14.2 & 10.2 & 11.8 & 6.4 & 368.55 & male & yes & no & no & no \\
\hline 18 & $4 / 25 / 2001$ & $\checkmark$ & & & & 291621.44 & 945456.11 & 13.9 & 9.8 & 11.8 & 6.2 & 425.25 & male & no & yes & no & no \\
\hline 19 & $4 / 25 / 2001$ & $\checkmark$ & & & & 291613.88 & 945436.87 & 12.7 & 8.6 & 11.1 & 5.3 & 340.2 & male & no & yes & no & no \\
\hline 20 & $4 / 26 / 2001$ & $\checkmark$ & & & & 291613.88 & 945436.87 & 13.1 & 9.5 & 11.2 & 6.2 & 283.5 & male & yes & yes & no & no \\
\hline 21 & $4 / 26 / 2001$ & $\checkmark$ & & & & 291613.88 & 945436.87 & 12.3 & 8.9 & 10.5 & 5.3 & 311.85 & male & no & yes & no & no \\
\hline 22 & $4 / 26 / 2001$ & $\checkmark$ & & & & 291614.66 & 945437.05 & 18.1 & 13.2 & 15.7 & 8.1 & 963.9 & female & yes & yes & no & no \\
\hline 23 & $4 / 26 / 2001$ & $\checkmark$ & & & & 291613.88 & 945436.87 & 14 & 9.8 & 12.1 & 6.2 & 481.95 & male & yes & yes & no & yes \\
\hline 24 & $4 / 27 / 2001$ & $\checkmark$ & & & & 291613.88 & 945436.87 & 17.4 & 13.2 & 15.4 & 8.5 & 992.25 & female & no & no & no & no \\
\hline 25 & $4 / 27 / 2001$ & $\checkmark$ & & & & 291610.33 & 945436.04 & 14.5 & 11.1 & 12.8 & 6.8 & 538.65 & -- & yes & yes & no & no \\
\hline 26 & $4 / 27 / 2001$ & $\checkmark$ & & & & 291613.88 & 945436.87 & 13.4 & 9.7 & 11.4 & 5.7 & 368.55 & male & yes & yes & yes & no \\
\hline 27 & $4 / 27 / 2001$ & $\checkmark$ & & & & 291613.88 & 945436.87 & 13.2 & 9.7 & 11.1 & 5.5 & 113.4 & male & no & yes & no & no \\
\hline 28 & $4 / 27 / 2001$ & $\checkmark$ & & & & 291613.88 & 945436.87 & 14.2 & 10.1 & 11.7 & 6.2 & 368.55 & male & yes & yes & yes & no \\
\hline 29 & $4 / 27 / 2001$ & $\checkmark$ & & & & 291613.88 & 945436.87 & 13 & 9 & 10.8 & 5.1 & 255.15 & male & no & yes & yes & no \\
\hline 30 & $4 / 27 / 2001$ & & & $\checkmark$ & & 291616.88 & 945433.27 & 18.1 & 13.1 & 16.4 & 8.7 & 992.25 & female & no & yes & no & no \\
\hline 31 & $4 / 27 / 2001$ & & & $\checkmark$ & & 291612.70 & 945436.76 & 12 & 8.7 & 10.5 & 5.5 & 283.5 & male & yes & yes & no & no \\
\hline 32 & $4 / 28 / 2001$ & $\checkmark$ & & & & 291613.88 & 945436.87 & 20.1 & 13 & 17.3 & 9.9 & $1,360.8$ & female & yes & yes & no & no \\
\hline 33 & $4 / 28 / 2001$ & $\checkmark$ & & & & 291613.88 & 945436.87 & 17.9 & 13.3 & 16 & 8.5 & 538.65 & female & yes & yes & no & no \\
\hline 34 & $4 / 28 / 2001$ & $\checkmark$ & & & & 291613.88 & 945436.87 & 13.1 & 9.6 & 11.3 & 5.5 & 255.15 & male & no & yes & no & no \\
\hline
\end{tabular}


Table 2. Summary of terrapin capture and biometric data, South Deer Island, Texas, April 2001-May 2002-Continued

\begin{tabular}{|c|c|c|c|c|c|c|c|c|c|c|c|c|c|c|c|c|c|}
\hline \multirow{4}{*}{$\begin{array}{c}\text { Num- } \\
\text { ber }\end{array}$} & \multirow{4}{*}{ Date } & \multicolumn{6}{|c|}{ Capture data } & \multicolumn{10}{|c|}{ Biometric data } \\
\hline & & \multicolumn{3}{|c|}{ Survey type } & \multirow{3}{*}{$\begin{array}{l}\text { Recap- } \\
\text { tured }\end{array}$} & \multirow{2}{*}{\multicolumn{2}{|c|}{$\begin{array}{c}\text { Location } \\
\text { (decimal degrees) }\end{array}$}} & \multirow{2}{*}{\multicolumn{2}{|c|}{$\begin{array}{l}\text { Straight-line } \\
\text { carapace size }\end{array}$}} & \multirow{2}{*}{\multicolumn{2}{|c|}{$\begin{array}{l}\text { Straight-line } \\
\text { plastron size }\end{array}$}} & \multirow{3}{*}{$\begin{array}{l}\text { Mass } \\
\text { (grams) }\end{array}$} & \multirow{3}{*}{ Sex } & \multicolumn{4}{|c|}{ Anomalies } \\
\hline & & \multicolumn{2}{|c|}{ Occurrence } & \multirow{2}{*}{$\begin{array}{c}\text { Nesting } \\
\text { and } \\
\text { basking }\end{array}$} & & & & & & & & & & & & & \\
\hline & & $\begin{array}{l}\text { Crab } \\
\text { trap }\end{array}$ & $\begin{array}{c}\text { La- } \\
\text { goon }\end{array}$ & & & Latitude & Longitude & $\begin{array}{l}\text { Length } \\
\text { (cm) }\end{array}$ & $\begin{array}{l}\text { Width } \\
\text { (cm) }\end{array}$ & $\begin{array}{l}\text { Length } \\
\text { (cm) }\end{array}$ & $\begin{array}{l}\text { Width } \\
\text { (cm) }\end{array}$ & & & $\begin{array}{l}\text { Bar- } \\
\text { nacles }\end{array}$ & Algae & $\begin{array}{l}\text { Le- } \\
\text { sions }\end{array}$ & $\begin{array}{l}\text { Derorm- } \\
\text { ities }\end{array}$ \\
\hline 35 & $4 / 28 / 2001$ & $\checkmark$ & & & & 291608.28 & 945442.99 & 13.8 & 9.9 & 11.8 & 6.3 & 368.55 & male & no & yes & no & no \\
\hline 36 & $4 / 28 / 2001$ & $\checkmark$ & & & & 291608.28 & 945442.99 & 14.3 & 10.4 & 11.9 & 6.5 & 368.55 & male & no & yes & yes & no \\
\hline 37 & $4 / 28 / 2001$ & $\checkmark$ & & & & 291608.28 & 945442.99 & 14 & 10 & 11.6 & 6 & 396.9 & male & no & yes & no & no \\
\hline 38 & $4 / 28 / 2001$ & $\checkmark$ & & & & 291608.28 & 945442.99 & 12.9 & 9.5 & 10.8 & 5.8 & 311.85 & male & no & yes & no & no \\
\hline 39 & $4 / 28 / 2001$ & $\checkmark$ & & & & 291608.28 & 945442.99 & 13.1 & 9.3 & 11.1 & 5.8 & 368.55 & male & yes & yes & no & no \\
\hline 40 & $4 / 28 / 2001$ & $\checkmark$ & & & & 291608.28 & 945442.99 & 13.7 & 9.9 & 11.3 & 6.4 & 340.2 & male & no & yes & no & no \\
\hline 41 & 4/28/2001 & $\checkmark$ & & & & 291608.28 & 945442.99 & 12.7 & 8.8 & 10.9 & 5.8 & 311.85 & male & yes & yes & no & no \\
\hline 42 & $4 / 28 / 2001$ & $\checkmark$ & & & & 291608.28 & 945442.99 & 12.2 & 9.1 & 10.5 & 5.6 & 255.15 & male & no & yes & no & no \\
\hline 43 & $4 / 28 / 2001$ & $\checkmark$ & & & & 291608.28 & 945442.99 & 12.5 & 9.4 & 10.5 & 5.7 & 283.5 & male & no & yes & no & no \\
\hline 44 & $4 / 28 / 2001$ & $\checkmark$ & & & & 291608.28 & 945442.99 & 12.7 & 9.3 & 10.6 & 5.7 & 311.85 & male & no & yes & no & no \\
\hline 45 & $4 / 28 / 2001$ & $\checkmark$ & & & & 291608.28 & 945442.99 & 12.7 & 9.4 & 11 & 6.9 & 311.85 & male & yes & yes & no & no \\
\hline 46 & $4 / 28 / 2001$ & $\checkmark$ & & & & 291608.28 & 945442.99 & 13.7 & 10 & 11.3 & 5.9 & 368.55 & male & yes & yes & yes & yes \\
\hline 47 & $4 / 28 / 2001$ & $\checkmark$ & & & & 291608.28 & 945442.99 & 12.8 & 9.1 & 10.9 & 5.5 & 311.85 & male & no & yes & no & no \\
\hline 48 & $5 / 9 / 2001$ & & & $\checkmark$ & & 291609.45 & 945443.32 & -- & -- & -- & -- & -- & female & -- & -- & -- & -- \\
\hline 49 & $5 / 9 / 2001$ & $\checkmark$ & & & $\checkmark$ & 291614.16 & 945436.56 & 12.7 & 9.2 & 10.5 & 5.7 & -- & male & no & yes & no & no \\
\hline 50 & $5 / 9 / 2001$ & $\checkmark$ & & & & 29160796 & 945441.19 & 18.9 & 13.3 & 16.6 & 8.6 & $1,190.7$ & female & yes & yes & no & no \\
\hline 51 & $5 / 9 / 2001$ & $\checkmark$ & & & & 291614.16 & 945436.56 & 13 & 9.7 & 10.6 & 5.7 & 368.55 & male & no & yes & no & no \\
\hline 52 & $5 / 9 / 2001$ & $\checkmark$ & & & $\checkmark$ & 291616.53 & 945432.17 & 18.6 & 13.3 & 16.2 & 8.8 & $1,275.75$ & female & no & yes & no & no \\
\hline 53 & $5 / 9 / 2001$ & $\checkmark$ & & & & 291610.90 & 945448.99 & 19.1 & 13.2 & 16.5 & 8.7 & $1,162.35$ & female & no & yes & no & no \\
\hline 54 & $5 / 10 / 2001$ & $\checkmark$ & & & & 291614.16 & 945436.56 & 17.7 & 13.2 & 15.9 & 8.6 & $1,048.95$ & female & no & yes & no & no \\
\hline 55 & $5 / 10 / 2001$ & $\checkmark$ & & & & 291614.16 & 945436.56 & 17.4 & 13.2 & 15.2 & 8.3 & 567 & female & no & yes & no & no \\
\hline 56 & $5 / 10 / 2001$ & $\checkmark$ & & & & 291616.53 & 945432.17 & 18.5 & 12.8 & 16.3 & 8.1 & 1,134 & female & no & yes & no & no \\
\hline 57 & $5 / 10 / 2001$ & $\checkmark$ & & & $\checkmark$ & 291614.16 & 945436.56 & 13.1 & 9.2 & 10.9 & 5.8 & 368.55 & male & yes & yes & no & no \\
\hline 58 & $5 / 10 / 2001$ & $\checkmark$ & & & $\checkmark$ & 291614.16 & 945436.56 & 14.5 & 10.9 & 12.9 & 6.8 & 283.5 & female & yes & yes & no & no \\
\hline 59 & $5 / 10 / 2001$ & $\checkmark$ & & & $\checkmark$ & 291614.16 & 945436.56 & 12.5 & 9.3 & 10.6 & 5.8 & 368.55 & male & no & yes & no & no \\
\hline 60 & $5 / 10 / 2001$ & $\checkmark$ & & & & 291614.16 & 945436.56 & 12.7 & 9.1 & 10.7 & 5.6 & 283.5 & male & no & yes & no & no \\
\hline 61 & $5 / 10 / 2001$ & $\checkmark$ & & & & 291613.54 & 945436.26 & 13 & 9 & 10.7 & 5 & 311.85 & male & no & yes & no & no \\
\hline 62 & $5 / 10 / 2001$ & $\checkmark$ & & & & 291609.74 & 945437.66 & 18.2 & 13.6 & 16.1 & 8.5 & $1,162.35$ & female & no & yes & no & no \\
\hline 63 & $5 / 10 / 2001$ & $\checkmark$ & & & & 291609.74 & 945437.66 & 17.9 & 13.6 & 16.2 & 8.3 & 1,134 & female & no & yes & no & no \\
\hline 64 & $5 / 10 / 2001$ & $\checkmark$ & & & & 291609.74 & 945437.66 & 12.7 & 9.2 & 10.7 & 5.7 & 340.2 & male & no & yes & no & no \\
\hline 65 & $5 / 10 / 2001$ & $\checkmark$ & & & & 291614.16 & 945436.56 & 13.1 & 9.4 & 11.2 & 6.9 & 425.25 & male & yes & yes & no & no \\
\hline 66 & $5 / 10 / 2001$ & & & $\checkmark$ & & 291613.54 & 945434.27 & 12.2 & 9 & 10.5 & 5.5 & 311.85 & male & no & yes & no & no \\
\hline 67 & $5 / 10 / 2001$ & $\checkmark$ & & & & 291614.16 & 945436.56 & 13.1 & 9.4 & 10.8 & 5.4 & 396.9 & male & no & yes & no & no \\
\hline 68 & $5 / 11 / 2001$ & $\checkmark$ & & & & 291609.21 & 945445.57 & 17.9 & 13.3 & 15.7 & 8.8 & 1,134 & female & no & yes & no & no \\
\hline
\end{tabular}


Table 2. Summary of terrapin capture and biometric data, South Deer Island, Texas, April 2001-May 2002—Continued

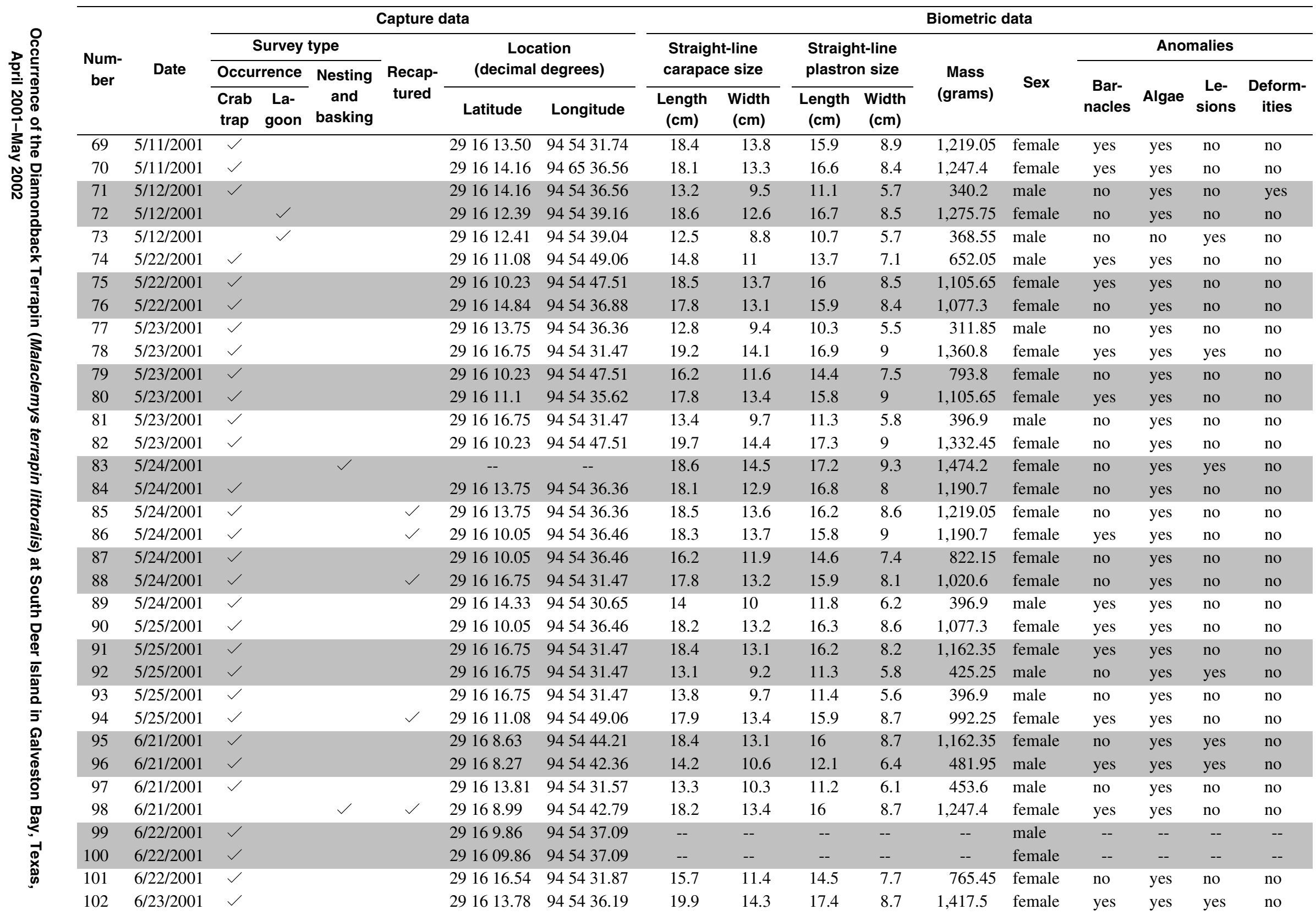


Table 2. Summary of terrapin capture and biometric data, South Deer Island, Texas, April 2001-May 2002-Continued

\begin{tabular}{|c|c|c|c|c|c|c|c|c|c|c|c|c|c|c|c|c|c|}
\hline \multirow{4}{*}{$\begin{array}{l}\text { Num- } \\
\text { ber }\end{array}$} & \multirow{4}{*}{ Date } & \multicolumn{6}{|c|}{ Capture data } & \multicolumn{10}{|c|}{ Biometric data } \\
\hline & & \multicolumn{3}{|c|}{ Survey type } & \multirow{3}{*}{$\begin{array}{l}\text { Recap- } \\
\text { tured }\end{array}$} & \multirow{2}{*}{\multicolumn{2}{|c|}{$\begin{array}{c}\text { Location } \\
\text { (decimal degrees) }\end{array}$}} & \multirow{2}{*}{\multicolumn{2}{|c|}{$\begin{array}{l}\text { Straight-line } \\
\text { carapace size }\end{array}$}} & \multirow{2}{*}{\multicolumn{2}{|c|}{$\begin{array}{l}\text { Straight-line } \\
\text { plastron size }\end{array}$}} & \multirow{3}{*}{$\begin{array}{c}\text { Mass } \\
\text { (grams) }\end{array}$} & \multirow{3}{*}{ Sex } & \multicolumn{4}{|c|}{ Anomalies } \\
\hline & & \multicolumn{2}{|c|}{ Occurrence } & \multirow{2}{*}{$\begin{array}{c}\text { Nesting } \\
\text { and } \\
\text { basking }\end{array}$} & & & & & & & & & & & & & \\
\hline & & $\begin{array}{l}\text { Crab } \\
\text { trap }\end{array}$ & $\begin{array}{c}\text { La- } \\
\text { goon }\end{array}$ & & & Latitude & Longitude & $\begin{array}{l}\text { Length } \\
\text { (cm) }\end{array}$ & $\begin{array}{l}\text { Width } \\
\text { (cm) }\end{array}$ & $\begin{array}{l}\text { Length } \\
\text { (cm) }\end{array}$ & $\begin{array}{l}\text { Width } \\
\text { (cm) }\end{array}$ & & & nacles & Algae & $\begin{array}{l}\text { Le- } \\
\text { sions }\end{array}$ & $\begin{array}{l}\text { ities } \\
\text { intorm- }\end{array}$ \\
\hline 103 & $6 / 23 / 2001$ & $\checkmark$ & & & & 291613.81 & 945431.57 & 17.1 & 12.8 & 15.9 & 8.3 & $1,077.3$ & female & no & yes & no & no \\
\hline 104 & $6 / 23 / 2001$ & $\checkmark$ & & & & 291613.81 & 945431.57 & 15.5 & 11.1 & 13.7 & 6.8 & 652.05 & female & no & yes & no & no \\
\hline 105 & $6 / 23 / 2001$ & $\checkmark$ & & & & 291613.81 & 945431.57 & 16.3 & 12.2 & 15.2 & 7.8 & 822.15 & female & no & yes & no & no \\
\hline 106 & $6 / 23 / 2001$ & $\checkmark$ & & & & 291614.53 & 945436.73 & 11.90 & 8.8 & 10.4 & 5.2 & 283.5 & male & no & yes & no & no \\
\hline 107 & $7 / 17 / 2001$ & $\checkmark$ & & & & 291611.08 & 945436.26 & 18.6 & 13.5 & 16.1 & 8.4 & 935.55 & female & no & yes & no & no \\
\hline 108 & $7 / 17 / 2001$ & $\checkmark$ & & & & 291613.43 & 945435.83 & 16.4 & 11.4 & 14.9 & 7 & 708.75 & female & no & yes & no & no \\
\hline 109 & $7 / 17 / 2001$ & $\checkmark$ & & & & 291613.43 & 945435.83 & 13.4 & 9.6 & 11.5 & 5.8 & 340.2 & male & yes & yes & no & no \\
\hline 110 & $7 / 17 / 2001$ & $\checkmark$ & & & & 291613.43 & 945435.83 & 16.9 & 12.3 & 14.8 & 7.6 & 765.45 & female & no & yes & yes & no \\
\hline 111 & $7 / 20 / 2001$ & $\checkmark$ & & & $\checkmark$ & 291615.62 & 945431.03 & 19.7 & 14.6 & 17.3 & 9.3 & $1,360.8$ & female & no & yes & no & no \\
\hline 112 & $7 / 20 / 2001$ & & $\checkmark$ & & $\checkmark$ & 291612.63 & 945440.49 & 17.7 & 13.2 & 15.5 & 8.5 & 1,134 & female & no & yes & no & no \\
\hline 113 & $7 / 20 / 2001$ & & $\checkmark$ & & & 291612.01 & 945440.79 & 14.1 & 10 & 11.2 & 6 & 425.25 & male & yes & yes & no & no \\
\hline 114 & $7 / 20 / 2001$ & & $\checkmark$ & & & 291615.64 & 945443.81 & 12.9 & 9.1 & 11.8 & 5.9 & 368.55 & male & no & yes & no & no \\
\hline 115 & $8 / 25 / 2001$ & $\checkmark$ & & & $\checkmark$ & 291611.5 & 945432.7 & 19.1 & 13.9 & 16.9 & 8.7 & $1,190.7$ & female & yes & yes & no & no \\
\hline 116 & $9 / 24 / 2001$ & $\checkmark$ & & & & 291608.3 & 945436.7 & 17.8 & 13.4 & 16.4 & 8.5 & $1,304.1$ & female & yes & yes & no & no \\
\hline 117 & $9 / 24 / 2001$ & $\checkmark$ & & & $\checkmark$ & 291611.5 & 945432.7 & 18.7 & 13.5 & 17.3 & 8.3 & $1,275.75$ & female & no & yes & no & no \\
\hline 118 & $9 / 24 / 2001$ & $\checkmark$ & & & $\checkmark$ & 291611.5 & 945432.7 & 18.3 & 13.5 & 16.2 & 8.3 & 1,134 & female & no & yes & no & no \\
\hline 119 & $9 / 25 / 2001$ & & $\checkmark$ & & $\checkmark$ & 291615.2 & 945442.9 & 18.4 & 13.3 & 16.9 & 8.4 & $1,304.1$ & female & no & yes & no & no \\
\hline 120 & $3 / 21 / 2002$ & $\checkmark$ & & & & 291616.2 & 945429.9 & 15.4 & 11.1 & 13.6 & 7.3 & 680.4 & female & yes & yes & no & no \\
\hline 121 & $3 / 21 / 2002$ & $\checkmark$ & & & & 291616.2 & 945429.9 & 15.2 & 11.2 & 13.9 & 7.2 & 680.4 & female & no & yes & no & no \\
\hline 122 & $3 / 21 / 2002$ & & $\checkmark$ & & & 291614.6 & 945441.6 & 13.3 & 9.5 & 11.1 & 5.8 & 396.9 & male & no & yes & no & no \\
\hline 123 & $3 / 24 / 2002$ & $\checkmark$ & & & & 291613.6 & 945436.2 & 12.6 & 9.2 & 10.9 & 5.7 & 311.85 & male & no & yes & yes & no \\
\hline 124 & $4 / 26 / 2002$ & & & $\checkmark$ & $\checkmark$ & 291610 & 945443.2 & 19 & 14.2 & 16.5 & 9 & $1,332.45$ & female & yes & yes & no & no \\
\hline 125 & $4 / 30 / 2002$ & $\checkmark$ & & & $\checkmark$ & 291616.2 & 945429.9 & 18.2 & 13.3 & 16.2 & 8.3 & $1,048.95$ & female & yes & yes & no & no \\
\hline 126 & $4 / 30 / 2002$ & $\checkmark$ & & & & 291616.2 & 945429.9 & 19.3 & 13.7 & 17.4 & 8.7 & $1,275.75$ & female & yes & yes & no & no \\
\hline 127 & $4 / 30 / 2002$ & $\checkmark$ & & & & 291616.2 & 945429.9 & 16.2 & 11.1 & 14.7 & 7.1 & 793.8 & female & no & yes & no & no \\
\hline 128 & $4 / 30 / 2002$ & $\checkmark$ & & & & -- & -- & 14.8 & 11.2 & 13.1 & 6.7 & 453.6 & female & no & yes & no & no \\
\hline 129 & $4 / 30 / 2002$ & $\checkmark$ & & & & 291613.6 & 945436.2 & 12.8 & 9.2 & 10.8 & 5.5 & 368.55 & male & no & yes & no & no \\
\hline 130 & $4 / 30 / 2002$ & & $\checkmark$ & & & 291614.3 & 945441.4 & 17.8 & 13 & 15.4 & 8.3 & 935.55 & female & no & no & no & no \\
\hline 131 & $5 / 2 / 2002$ & & $\checkmark$ & & $\checkmark$ & 291617.3 & 945434.7 & 13.3 & 9.6 & 11.2 & 6 & 396.9 & male & no & yes & no & no \\
\hline 132 & $5 / 3 / 2002$ & $\checkmark$ & & & & 291613.6 & 945436.2 & 13.2 & 9.4 & 10.6 & 5.9 & 340.2 & male & no & yes & no & no \\
\hline 133 & $5 / 3 / 2002$ & $\checkmark$ & & & & 291613.6 & 945436.2 & 16.1 & 12 & 14.4 & 7.3 & 822.15 & female & yes & yes & no & no \\
\hline 134 & $5 / 3 / 2002$ & $\checkmark$ & & & & 291613.6 & 945436.2 & 14.3 & 10.2 & 11.8 & 6.3 & 453.6 & male & yes & & no & no \\
\hline 135 & $5 / 3 / 2002$ & $\checkmark$ & & & & 291613.6 & 945436.2 & 17.7 & 11.8 & 16 & 7.5 & 822.15 & female & no & yes & no & no \\
\hline
\end{tabular}


Table 3. Maximums of field parameters recorded during periods of terrapin collection, South Deer Island, Texas, April 2001-May 2002

$[--$, no data $]$

\begin{tabular}{lccccc}
\hline \multicolumn{1}{c}{ Month } & $\begin{array}{c}\text { Temperature } \\
\text { (degrees } \\
\text { Celsius) }\end{array}$ & $\begin{array}{c}\text { Salinity } \\
\text { (dissolved solids) } \\
\text { (milligrams per liter) }\end{array}$ & $\begin{array}{c}\text { Dissolved oxygen } \\
\text { (milligrams } \\
\text { per liter) }\end{array}$ & $\begin{array}{c}\text { Conductivity } \\
\text { (microsiemens } \\
\text { per centimeter at } \\
\text { 25 degrees Celsius) }\end{array}$ & $\begin{array}{c}\text { pH } \\
\text { (standard } \\
\text { units) }\end{array}$ \\
\hline July 2001 & 35.6 & 2,740 & 7.6 & 43,000 & 8.9 \\
August 2001 & 36.3 & 3,320 & 6.9 & 51,200 & 9.0 \\
September 2001 & 26.9 & 2,100 & 8.5 & 33,500 & 8.0 \\
October 2001 & 22.9 & 2,140 & 9.9 & 33,900 & 8.6 \\
November 2001 & 15.3 & 2,140 & 11 & 34,000 & 8.2 \\
December 2001 & 16.6 & 1,970 & 10 & 31,500 & 8.1 \\
January 2002 & 14.0 & -- & 9.5 & 36,700 & 8.2 \\
February 2002 & 19.4 & -- & 9.4 & 35,800 & 7.9 \\
March 2002 & 22.4 & 2,280 & 8.9 & 36,500 & 8.0 \\
April-May 2002 & 28.4 & 2,030 & 7.3 & 32,400 & 8.0 \\
\hline
\end{tabular}

Table 4. Vegetation species or substrate with at least 20 percent relative frequency along six transects, South Deer Island, Texas, April 2001-May 2002

[Transect locations shown in figure 2]

\begin{tabular}{clc}
\hline Transect & Species or substrate & $\begin{array}{c}\text { Relative frequency } \\
\text { (percent) }\end{array}$ \\
\hline A & Shell (pieces/crushed) & 21 \\
& Saltwort & 74 \\
B & Shell (pieces/crushed) & 22 \\
& Woody debris & 28 \\
& Slender seapurslane & 34 \\
C & Shell (pieces/crushed) & 49 \\
D & Slender seapurslane & 24 \\
& Shell (pieces/crushed) & 32 \\
& Slender seapurslane & 20 \\
E & Shell (pieces/crushed) & 34 \\
& & 43 \\
F & Seabeach orache & 46 \\
\hline
\end{tabular}

